\title{
Performance effects of external search strategies in European small and medium- sized enterprises
}

\begin{abstract}
There is little evidence regarding the performance impact of open innovation on SMEs, especially across different firm-size categories and sectors. Using new survey data from 28 European countries, we specify ordered logit and generalized proportional odds models to explore how seven individual external search strategies (knowledge sources) affect SME innovation performance across different size categories and sectors. While we find some consistently positive effects, in particular from using customers as an external knowledge source, we also find that some search strategies may not be beneficial. These findings suggest managerial and policy implications.
\end{abstract}




\section{Introduction}

This study explores how external search strategies, as a type of open innovation (OI) practice, impact innovation performance in European small and medium-sized enterprises (SMEs). The concept of open innovation introduced by Chesbrough (2003) reignited the stream of research focusing on how firms' interactions with the external environment affect their innovation activities. The concept is multifaceted and encompasses several dimensions and practices (Dahlander and Gann 2010; Huizingh2011; Schroll and Mild 2011; Spithoven, Vanhaverbeke, and Roijakkers 2013; Verbano, Crema, and Venturini forthcoming). The main distinction is made between inbound and outbound OI practices, with recognition of the third practice of coupled OIs. Inbound OIs encompass external search for knowledge sources ${ }^{1}$ that should enhance firms' innovativeness; outbound OIs refer to the commercialization phase of the innovation process; and coupled OIs refer to formal cooperative networking, such as strategic alliances and joint ventures (Mazzola, Bruccoleri, and Perrone 2012).

As the investigation of OI has been mostly focused on large firms, recent attempts have been made to explore how SMEs adopt OI practices as well as the impact on SME innovation performance of opening up the innovation process (see for instance, Brunswicker and Vanhavebeke 2014; Lee et al. 2010; Mazzola, Bruccoleri, and Perrone 2012; Parida, Westerberg, and Frishammar 2012; Spithoven, Vanhaverbeke, and Roijakkers 2013; Van de Vrande et al. 2009; Van de Vrande, Vanhaverbeke, and Gassmann 2010). However, given that SMEs are a heterogeneous group, our study attempts to shed light on the performance effects of OI practices in each firm size category of micro, small and medium-sized firms. In this respect, the study responds to the recommendation by Spithoven, Vanhaverbeke, and Roijakkers (2013) to investigate OI practices within different categories of SMEs.

Furthermore, this study is among only a few to provide empirical evidence on the performance effects of OIs in SMEs operating in different industries. Most research to date focuses on high-tech manufacturing firms (Chiaroni, Chiesa, and Frattini 2011; Van de Vrande,Vanhaverbeke, and Gassmann 2010), which limits our understanding of OI practices in other manufacturing and

\footnotetext{
${ }^{1}$ External search, search strategies, external knowledge flows and external knowledge sources are used interchangeably in the open innovation literature.
} 
service sectors (Grimpe and Sofka 2009; Muscio 2007). Other sectors are important contributors to modern economies, insofar as the largest contribution to employment and production in contemporary manufacturing comes from medium-low-technology and low-technology industries (Grimpe and Sofka 2009; OECD 2006) with traditional manufacturing continuing to make a major contribution (Radicic et al, 2015), while the service sector accounts for more than $70 \%$ of value added in OECD countries (Mention 2011). Accordingly, the study investigates how external search aspects of open innovation affect innovation performance of SMEs in high- and low-tech industries, ICT and service sectors.

The study utilizes a cross-section sample of SMEs in manufacturing, Information and Communication Technology (ICT) and service sectors located in 27 EU countries and Bosnia and Herzegovina. Studies focusing on OI practices usually investigate innovation activities within the boundaries of one or a few countries at most (Schroll and Mild 2011). By investigating the influence of OI strategies on SME innovation performance in 28 European countries, this study attempts a comprehensive quantitative analysis of the impact of OI practices on SME innovation performance.

The remainder of this paper is structured in five sections. First, we draw on the OI literature to formulate hypotheses about the effects of OI on SME innovation performance. Subsequently, the methodology is reviewed, followed by presentation of the main results and discussion of the main findings. The final section presents implications for managers, researchers and policymakers, and notes limitations of the study, some of which may provide suggestions for future research.

\section{Theoretical framework}

The purpose of this section is to outline theoretical explanations of OI which, in turn, motivate our focus not only on the performance effects of SME OI practices but also on potential heterogeneities in the performance effects of OI practices within the aggregate SME category. First, we review management theories that predate the OI literature. These provide arguments as to why firms might engage in OI practices, in particular inbound OI and external search strategies, yet without identifying particular types of OI or, hence, their respective effectiveness. Secondly, we review the small literature that reports heterogeneous propensity to conduct OI and external search 
strategies among the different size categories of SMEs. However, this literature provides no guidance on potentially heterogeneous performance effects. In the third sub-section, therefore, we advance theoretical arguments as to why not only the propensity to conduct but also the performance effects of OI may be inversely related to firm size. Finally, we review empirical studies to inform hypotheses on particular types of OI, and, hence, the specification of our empirical models.

\section{Management theories in relation to open innovation}

Open innovation is defined as "the use of purposive inflows and outflows of knowledge to accelerate internal innovation, and to expand the markets for external use of innovation, respectively" (Chesbrough, Vanhaverbeke, and West 2006, p.1). The concept of open innovation encompasses two distinct types of innovation activities. Inbound OI (technology exploration or acquisition) refers to the use of external sources of knowledge (that is, external search), which enhance and complement internal technological capabilities. Outbound OI (technology exploitation or commercialization) is associated with the commercialization phase of the innovation process, whereby firms outsource market expansion to external organizations that are better suited to commercialize existing technologies (Chesbrough and Crowther 2006; Dahlander and Gann 2010; Van de Vrande et al. 2009). Additionally, Gassmann and Enkel (2004) identify the coupled OI practices, which correspond to cooperation for innovation with other businesses in strategic networks.

Research on OI follows the practice-based approach, whereby the understanding of the concept arises from observing changes in management practices related to OI (Vanhaverbeke and Cloodt 2014, p. 256), rather than from a newly formulated theoretical framework. Nonetheless, several economic and managerial theories yield insights into OI practices, although no single theory fully explains how and why firms open up their innovation process. As recent contributions argue (Gesing et al. 2015; Van de Vrande,Vanhaverbeke, and Gassmann 2010; Vanhaverbeke and Cloodt 2014, p. 256), transaction costs economics, the relational view of the firm, resource-based theories including dynamic capabilities - and the concept of absorptive capacity should be brought together in a unified theoretical framework. In the absence of such a unified framework, we suggest that the 
resource-based perspective and the closely associated concept of absorptive capacity are particularly useful.

Open innovation is closely related to the concept of absorptive capacity (Cohen and Levinthal1990). Defined as firms' capacity to explore, assimilate and apply external knowledge, absorptive capacity is contingent on firms' existing knowledge base. Zahra and George (2002) distinguish between potential and realized absorptive capacity, whereby the former refers to firms' ability to identify external knowledge sources, and the latter is associated with the extent to which firms benefit from those sources. Absorptive capacity, which is usually a result of firms' internal R\&D activities, is then complementary to OI practices (Chesbrough and Crowther 2006; Cohen and Levinthal 1990; Dahlander and Gann 2010; Schroll and Mild 2011; Spithoven, Clarysse, and Knockaert 2010).

OI practices require both internal and external resources. While both the resource-based view of the firm and OI emphasize the importance of resources, the former points towards independence and competition among firms, but the latter recognizes the interdependence of complementary assets in achieving benefits from openness. However, there is an alternative view on the role of the resourcebased theory in explaining OI practices. Some authors (see, for example, Vega-Jurado, GutiérrezGracia, and Fernández-de-Lucio 2009) argue that the resource-based view provides a theoretical framework on the use of external sources of knowledge, because it implies that firms should open up their innovation process to gain access to complementary inputs. The relational view of the firm (Dyer and Singh 1998) suggests that firms can gain competitive advantage by combining complementary resources in a unique manner, which is consistent with the OI framework (Gesing et al. 2015; Vanhaverbeke and Cloodt 2014, p. 270).

Consistent with these theoretical underpinnings of OI, Huang and Rice (2009) argue that the OI paradigm rests upon three building blocks. The first is firms' acquisition of external knowledge through a wide range of knowledge sources. In relation to this component of OI, external search strategies can be defined as the systematic exploration of the firms' environment in search of external knowledge (Ebersberger et al. 2012). Firms establish and maintain a wide range of external search channels and knowledge sources with other businesses (customers, suppliers, competitors) and with 
public institutions (HEIs, research centres, government organizations and so on) (Von Hippel 1988). Exploration of a wide range of knowledge sources increases the likelihood of a successful innovation outcome (Leiponen and Helfat 2010). The second building block is appropriation of returns to innovation, through inbound (acquisition of patents, trademarks, know-how and so on) and outbound (selling patents and other IPs to other firms) commercialization channels. Finally, the third building block is firms' internal innovative capacity, that is, absorptive capacity (Cohen and Levinthal 1990), which enables firms to search, retain and exploit external knowledge. Our models (below) empirically encompass all three components of the OI model: i.e. external search strategies; appropriation of returns to innovation; and absorptive capacity.

This study reports performance effects of OI practices, which as well as benefits may also entail costs. External search or sourcing is regarded as inbound, non-pecuniary innovation (Dahlander and Gann 2010; Laursen and Salter 2004). Benefits of external search are well documented (Spithoven, Vanhaverbeke, and Roijakkers 2013). By accessing external knowledge sources to foster the introduction of new products and services, firms can experience cost and time savings (Chesbrough 2003), shorter time to market (Huizingh 2011) and can create synergies in available internal and external resources and in developing new approaches to market (Dahlander and Gann 2010). However, the literature on OI also identifies potential costs and disadvantages that opening up of the innovation process might incur. First, employees might resist the acquisition of knowledge that is externally sourced, either by simply rejecting external ideas or under-utilizing external knowledge sources. This is known as the not-invented-here (NIH) syndrome (Katz and Allen1982). Chesbrough and Crowther (2006) report that the NIH syndrome and lack of internal commitment are the main barriers to OI. Second, interacting with external partners might entail high transaction costs due to coordination and communication costs and risks of opportunistic behaviour (Gans and Stern 2003). High transaction costs can be reduced if there is mutual trust between firms (see, for instance, Lee et al. 2010). 


\section{Open innovation and external search strategies in SMEs}

Theoretical insights from resource-based perspectives of the firm suggest that SME OI practices may be different from those of large firms. In general, the innovation literature suggests that SMEs innovate differently than do large firms because of differences in resources. The main disadvantage of SMEs in this respect is associated with limited financial resources (lack of internal financial funds for innovation, credit constraints) and human resources (lack of management and entrepreneurial competences, issues in employing and retaining skilled workers, lack of marketing expertise) (Lee et al. 2010; Parida, Westerberg, and Frishammar 2012; Rothwell and Zegveld 1982; Vossen 1998). Because of these limitations, the literature suggests that SMEs explore external opportunities and sources to compensate for the limitations in their own innovation capacity (Bianchi et al. 2010; Chesbrough, Vanhaverbeke, and West 2006; Lee et al. 2010; Muscio 2007; Parida, Westerberg, and Frishammar 2012; Van de Vrande et al. 2009). Potential benefits of opening up the innovation process are associated with access to technologies developed by other firms and/or jointly developing new technologies (Parida,Westerberg, and Frishammar 2012), reduced risk and cost and a shorter innovation period (Lee et al. 2010). Furthermore, limited financial and human resources influence the level of openness and types of OI strategies adopted by SMEs. Namely, SMEs mostly engage in user innovation (that is, customer involvement, as termed in the open innovation literature) and in external networking, particularly in informal networking (Parida, Westerberg, and Frishammar 2012; Van de Vrande et al. 2009). In contrast, SMEs rarely exploit other, more costly, sources of external knowledge, such as outward and inward IP licensing, venturing and external participation.

The resource-based theories suggesting that SME OI practices may be different from those of large firms also suggest potential heterogeneities at still higher levels of resolution; i.e. there may also be heterogeneities in OI practices corresponding to resource differentials between micro, small and medium firms. While Spithoven, Clarysse, and Knockaert (2010) suggest that SMEs in general could be more prone to exploit OI practices, because of their relatively limited absorptive capacity, Van de Vrande et al. (2009) find that medium-sized firms are more prone to opening up innovation processes than are small firms. However, neither suggested relationship between firm size and propensity to 
exploit OI is supported in our data. Across micro, small and medium enterprises, Appendix Table A1 shows only very small differences between the means and standard deviations in the use of seven individual search strategies. A composite, unweighted average across these seven activities shows a negative relationship between the self-reported propensity of firms to undertake search strategies (on a scale of 0-7 - from no activity to all seven search strategies) and firm size: micro firms have a mean response of 3.27; small firms of 3.06; and medium firms of 2.88. However, standard tests reveal no statistically significant differences between either these means or between the corresponding standard deviations (these calculations are available on request).

The literature on OI has so far focussed mainly on the propensity to conduct different OI practices. Both theory and empirical evidence suggests that SME OI practices may be different from those of large firms and so studies of OI practices should take account of potential heterogeneities by firm size. In turn, this suggestion may be applied to potential heterogeneities by firm size within the SME category, a topic on which as yet there is little empirical evidence.

In this paper, we focus on the performance effects of OI activities. Here both the theory and the evidence are particularly limited. We first review the empirical evidence on the performance effects of inbound OI practices in SMEs, which is heterogeneous and so far inconclusive. Then, we build on the propensity literature by proposing a theoretical rationale for why potential heterogeneities by firm size within the SME categories may apply not only to firms' propensity to conduct OI but also to the performance effects of OI.

\section{Empirical evidence and hypotheses development}

To date, the evidence on the performance effects of OI on European SMEs is limited. Parida,Westerberg, and Frishammar (2012) report a positive performance impact of technology sourcing and scouting on radical and incremental innovation in Swedish SMEs. Brunswicker and Vanhaverbeke (2014) report a positive relationship between external search and innovation performance of European SMEs. In particular, they found that two sourcing strategies, full sourcing and application-oriented sourcing, enhance firms' innovation success. Full sourcing denotes a search strategy adopted by those SMEs that exploit an extensive range of knowledge sources (with 
customers, suppliers, competitors, universities and research organizations, experts for IPs, and network partners), while application-oriented sourcing refers to using knowledge sources in value chains, but particularly with customers. In contrast, Spithoven, Vanhaverbeke, and Roijakkers (2013) find no performance effect of open innovation on innovative sales among Belgian SMEs. However, as yet, no study has focussed on potential performance heterogeneities of OI between micro, small and medium enterprises.

Our theoretical discussion on the propensity to conduct OI activities suggests heterogeneity between large firms and SMEs as well as between SMEs of different sizes. This could be a sufficient reason for applying the same principle to the less studied performance effects of OI on SMEs. However, beyond the force of analogy, we argue that there is a theoretical reason for doing so. If, as we argue above, resource constraints are more binding the smaller the firm (other factors held constant) then the smaller the firm the greater the proportion of its potentially commercially successful innovation activities of all kinds - including OI - that the firm will be unable to undertake. In this case, allowing for diminishing returns as firms implement their successively "next best" innovation activities, the commercial returns to OI activities will be higher for smaller firms than for larger firms. Both the propensity literature and this reasoning specifically on the returns to OI - i.e. the performance effects - inform our main hypothesis.

Hypothesis 1: OI practices have a positive effect on innovation performance, but this effect is larger in micro and small firms than in medium sized firms.

Innovation or knowledge brokers are facilitators of innovation in that they are not the source of innovation but rather support the innovation process. As such, their critical characteristic is their impartial or independent position regarding network firms (Klerkx and Leeuwis2009). Knowledge brokers provide one way of overcoming market or system failures associated with the limited linkages between economic actors. Three basic functions of knowledge or innovation brokers are: i) demand articulation, i.e. identifying demand for innovation with respect to technology, knowledge, funding, and policy; ii) network formation, i.e. moderating the establishment of connections between cooperative partners; and iii) innovation process management, i.e. moderating learning and cooperation between relevant actors in the innovation process (Van Lente et al. 2003; Klerkx and 
Leeuwis 2009). Therefore, given their facilitating role in the innovation process, we investigate the following hypothesis.

Hypothesis 2. Online technology and knowledge brokers/intermediaries have a positive effect on SME innovation performance, regardless of the firm size.

The literature distinguishes between formal and informal ties. The main difference is that the former are based on contractual relationships, while the latter arise from the shared experience of network partners (Powell and Grodal 2005). Formal networking, through contractual agreements, prevents network partners from engaging in opportunistic behaviour and expropriation of intellectual property rights. Conversely, firms forge informal, non-contractual networking relations, to avoid costs and limitations related to contractual agreements (Huang and Rice 2009; Bascavusoglu-Moreau, Mina, and Hughes 2013). Using informal sources of knowledge is based on mutual trust and moral obligations and usually allows firms to explore and exploit tacit knowledge (Bascavusoglu-Moreau, Mina, and Hughes 2013). In contrast, establishing and maintaining informal ties might expose network firms to knowledge leakages, given the lack of contractual obligations and formal IP protection, in particular if they cooperate with competitors (Cassiman and Veuglers 2002).

Some evidence indicates that firms might prefer informal over formal ties, in particular smaller firms, due to their limited resources (Bascavusoglu-Moreau, Mina, and Hughes 2013). For instance, Forero-Pineda, Waldron and Ramirez (2010) found that both formal and informal networking has a positive impact on SME innovation performance, but informal has a larger performance effect than formal networking. In addition, Bascavusoglu-Moreau, Mina, and Hughes (2013) report a significant impact of both formal and informal OI activities on innovation in small firms, while in medium firms, only informal OIs have a positive and significant performance effect. This literature informs the following hypothesis.

\section{Hypothesis 3. Informal networking with other firms has a positive effect on SME innovation}

\section{performance.}

Moreover, tacit knowledge is particularly pertinent to university-industry informal ties (Bascavusoglu-Moreau, Mina, and Hughes 2013). Firms tend to engage in cooperation with universities and other research organizations to gain access to basic research and $R \& D$, and to 
develop new products until they are patentable (Zeng, Xie, and Tam 2010; McPherson and Vonortas 2012). Following this argument, we formulate the next hypothesis.

\section{Hypothesis 4. Informal networking with research organizations has a positive effect on SME}

\section{innovation performance.}

Although SMEs might be more inclined to informal networking with other firms (Van de Vrande et al. 2009), our data also allows us to investigate how formal networking through strategic alliances and non-equity alliances affect innovation performance. Narula and Hagedoorn (1999) refer to strategic alliances as cooperative agreements aimed at long-term profit optimisation. They argue that the form of cooperative agreement depends on the underlying motives: establishing and maintaining vertical cooperation with customers and suppliers is mainly motivated by cost reduction and short-term profit optimisation; alternatively, a main objective of establishing strategic alliances is enhancing the value of the firm and improving its long-term market position. Strategic alliances, as a mode of formal cooperation, enable network firms to mitigate the risk of opportunistic behaviour and expropriation of intellectual property rights (Opper and Nee 2015).

SMEs are less likely to form strategic alliances than are large firms, because a higher level of resources is needed for this type of open innovation (Narula and Hagedoorn 1999; Narula 2004). Furthermore, a high rate of failure of strategic alliances is also associated with the higher levels of investment and commitment required for this type of cooperation (Narula and Hagedoorn 1999). However, when SMEs cooperate through strategic alliances, this type of formal networking has a positive performance effect, implying its relevance as a source of external knowledge (Lee et al. 2010). Furthermore, irrespective of the firm size, strategic alliances as a form of networking on technology transfer are particularly relevant for capital and knowledge-intensive industries, where the introduction of product and process innovations entails high risk and uncertainty and where new technologies are constantly and rapidly developing (Narula and Hagedoorn 1999; Wynarczyk, Piperopoulos, and McAdam 2013).

Finally, non-equity alliances - i.e. contractual partnerships-in this study are defined as a type of alliance that is not based on formal economic return for either party. Following Hagedoorn (2002), non-equity alliances are more relevant for firms in high-tech and ICT sectors than for firms in 
medium and low-tech industries. Namely, the preferred form of partnering (equity alliances such as joint venturing or non-equity alliances) depends on the degree and speed of technological change, in that technological stability favours joint venturing, whereas rapid technological advances favour nonequity arrangements. This literature on types of formal network leads to the following hypothesis.

\section{Hypothesis 5. Strategic and non-equity alliances have positive effects on SME innovation}

performance.

The function of innovation networks is knowledge exchange between firms, public agencies, research organizations and other economic agents. Unlike knowledge networks to promote invention, innovation networks are characterized by knowledge creation for economic gain. The main characteristics of innovation networks are geographical proximity (similar to clusters), exchange of often tacit knowledge, the role of social capital as an enabler of knowledge transfers etc. Moreover, the key success factor of innovation networks is trust between network partners (Pinto, Noronha, and Faustino 2015). The theory of social capital posits that the position of the firm in the innovation network is a critical factor for its innovation performance, insofar as firms with the central position in the network are more innovative than peripheral ones. Further, the knowledge theory of the firm suggests that firms select network partners by searching for complementarities in knowledge and competences, i.e. firms that fit technologically with the focal firm (Savin and Egberokun 2013). Finally, Boschma (2005) suggests not only that geographical proximity can have positive effects on knowledge spillovers between network firms, but also that too much proximity can be detrimental to firms' innovation activities due to lock-in effects. These theories all suggest the contribution of different types of innovation networks to creating an environment - or ecosystem - more or less conducive to innovation. Together, they suggest the following broad hypothesis.

\section{Hypothesis 6. Belonging to ecosystems (innovation networks, $S \& T$ parks, clusters) has a positive}

\section{effect on SME innovation performance, unless firms experience lock-in effects.}

As previously noted, due to constraints in financial and human resources, the most frequent OI strategies adopted by SMEs are customer involvement and external networking (Parida, Westerberg, and Frishammar 2012; Teirlinck and Spithoven 2013; Van de Vrande et al. 2009). In addition, empirical studies on SME innovation performance usually report that cooperating with 
government institutions has no effect on firms' innovation performance (Zeng, Xie, and Tam 2010) or that vertical cooperation has a larger impact than other types of cooperation (Doloreux 2004). Customer involvement is among the first open innovation practices to be adopted in low-tech firms; but, more recently, other forms of cooperative networking, such as with suppliers, universities and knowledge brokers, are gaining importance among this category of firms. Zeng, Xie, and Tam (2010, p.185) suggest, based on their own as well as findings from numerous studies on the importance of cooperative partners for SME innovation: "Overall, the existing, relatively stable innovation-linkages for inter-firm relationships are mainly the vertical relationships among customers, suppliers and product or service providers." Limited by the available data, our final hypothesis addresses customer involvement as a source of SME innovation.

\section{Hypothesis 7. Customer involvement has a positive effect on SME innovation performance.}

In addition to investigating these research questions, we also contribute to the empirical literature on OI by investigating performance differences between sectors: high-tech; low-tech; Information and Communication Technology (ICT); and services. In the absence of existing theory and extensive empirical evidence - with the partial exception of Hypothesis 5 (above) - our reason for doing so is that industry differences have been found to be associated with firm-level differences in the propensity to undertake OI activities. Although OI started in high-technology industries, a recent trend shows that firms in low-technology industries are beginning to open up their innovation processes (Gassmann, Enkel, and Chesbrough 2010; Santamaría, Nieto, and Barge-Gil 2009).

Customer involvement is among the first OI practices to be adopted in low-tech firms but, more recently, other forms of cooperative networking, such as with suppliers, universities and knowledge brokers, are gaining importance among this category of firms. Grimpe and Sofka (2009) investigate complementarities between absorptive capacity and networking in the high- and lowtechnology industries across 13 European countries and found that, among various networking partners (customers, suppliers, competitors, universities and research centres), cooperation with customers has the most beneficial direct effect on absorptive capacity in low-technology firms.

An additional source of heterogeneity in the firm-level performance effects of OI may be differences between industrial sectors. Firms in the service sector innovate in different ways than do 
firms in manufacturing industries (Hipp and Grupp 2005; Mention 2011; Mina, BascavusogluMoreau, and Hughes 2014). However, empirical studies on OI practices in service sectors are scarce (Mention 2011; Mina, Bascavusoglu-Moreau, and Hughes 2014). Because of the nature of service sectors and their contribution to economic activities by providing human capital, rather than physical capital, firms operating in service sectors are strongly interrelated with other firms. Moreover, given their intangible nature, the literature suggests that service firms prefer informal cooperative ties and relational solutions based on mutual trust (Mina, Bascavusoglu-Moreau, and Hughes 2014; Vargo, Maglio, and Akaka 2008).

As theoretical considerations and empirical evidence on OI practices in medium-low and lowtechnologies industries are largely absent (Grimpe and Sofka 2009), and - to our knowledge completely absent with respect to OI performance effects, we investigate the performance effects of OI without formulating hypotheses about their expected performance effects in different sectors. In this respect, we conduct inductive research.

\section{Methodology}

\section{Data}

The dataset used in the analysis was gathered in 2010 within the MAPEER project commissioned by the European Commission's DG-Research (for more detailed information about the survey, see http://mapeer-sme.eu/.). The survey questionnaire covered the period 2005-2010. The sample includes 763 SMEs from 28 European countries but, due to missing values for some variables, the final sample used in the analysis includes 620 firms. The survey was targeted at the population of SMEs with fewer than 250 employees and an annual turnover of less than 50 million Euros (EU definition of SMEs - Article 2 of the Annex of Recommendation 2003/361/EC) (European Commission 2005). This definition is also consistent with the new European Commission (2008) guidelines. Moreover, Spithoven, Vanhaverbeke, and Roijakkers (2013) utilize the same definition of SMEs based on the headcount and note that it would be beneficial if other researchers were to follow this practice, and in that way enhance comparability of empirical findings in this stream of research. Within the group, micro-sized firms are defined as those with fewer than 10 employees, small firms with more than 10 
and fewer than 50 employees and medium-sized firms with more than 50 and fewer than 250 employees. The final sample consists of 304 micro firms, 200 small firms and 116 medium-sized firms. Given the small number of firms from individual countries, they were grouped into four categories following the European Innovation Scoreboard (European Commission 2011).

The European Innovation Scoreboard publishes the average innovation performance based on a composite index, encompassing 24 individual indicators grouped into five categories: three measuring innovation input; and two representing innovation outputs. Innovation performance of each Member State is then compared to the average innovation performance of the 27 EU Member States and each country is allocated to one of four groups (for the countries in each category, see Appendix Table A1).

- 'Innovation leaders', countries whose innovation performance is well above the EU27 average. Our sample includes 114 SMEs operating in four countries from this category.

- 'Innovation followers', countries with performance close to the EU27 average (198 firms in 10 countries);

- 'Moderate innovators', countries whose performance is below that of the EU27 average (242 firms in nine countries); and

- 'Modest innovators', representing countries whose performance is well below that of the EU27 average (66 firms in five countries).

The Innovation Scoreboard in 2011 refers to innovation performance in the years 2009/2010. Given that Bosnia and Herzegovina is not a member state, its innovation performance was evaluated to be modest, based on its low Gross Expenditure on Research and Development (GERD) of 0.02 percent of GDP for 2009 (UNESCO data, http://data.uis.unesco.org/). Grimpe and Sofka (2009) control for heterogeneity in national innovation systems by grouping $13 \mathrm{EU}$ countries relative to their GERD. However, given that R\&D expenditure is a measure of innovation input, we opted to control for distinct national innovation systems based on both innovation inputs and outputs. 


\section{Dependent variable}

In Appendix Table A1 we provide a detailed description of all variables in the model. The dependent variable is the share of sales from new products and/or processes (innovative sales) (as in Laursen and Salter 2006; Spithoven, Vanhaverbeke, and Roijakkers 2013).Innovative sales is the most frequently used measure of innovation output (Love, Roper, and Vahter 2014). Innovative sales is a direct innovation output, while patents measure an intermediate innovation output (Clarysse, Wright, and Mustare 2009; Pakes and Griliches 1980). Other measures of innovation output are the introduction of innovation (for example, whether the firm engages in product and process innovations) and the number of innovations (Acs and Audretsch 1988). The dataset at hand does not contain information on the introduction of innovations. However, Negassi (2004) suggests that innovative sales (as a turnover-based measure) could be more appropriate than the technological aspects of innovation (i.e. introduction of product and process innovation) in capturing the effect of non-R\&D innovation inputs which, we can assume, are pertinent to SMEs. Finally, innovative sales may depend not only on innovation performance but also on market and competition conditions. ${ }^{2}$ Accordingly, our empirical models address market and competition conditions by controlling for industry heterogeneity and competitive pressure at firm level.

Our initial categorical dependent variable had six scale categories: $=1$ if the share of sales from new products and/or processes is $0-10 \% ;=2$ if the share is $11-20 \% ;=3$ if the share is $21-30 \%$; $=4$ if the share is $31-40 \% ;=5$ if the share is $41-50 \%$; and $=6$ if the share is $>50 \%$. We used a convenient feature of two models to test whether the initial scale categories of the outcome variable were distinguishable: the stereotype logit model (Anderson 1984); and the multinomial logit model (see, for example, Long and Freese 2006, p.473). Testing within the framework of both approaches indicated that categories 2 and 3 as well as categories 4 and 5 are not distinguishable. Hence, we combined these pairs into new categories, which yields a dependent variable with four scale categories: $=1$ if the share is $0-10 \% ;=2$ if the share is $11-30 \% ;=3$ if the share is $31-50 \%$; and $=4$ if the share is $>50 \%$.

\footnotetext{
${ }^{2}$ We thank an anonymous referee for this point.
} 
For reasons explained below, neither of these models was our preferred estimator.

Nonetheless, this preliminary procedure proved its worth. When one of the preferred models - the generalized proportional odds/parallel-lines model - was estimated with the initial six-category dependent variable, it gave rise to a large number of negative in-sample predicted values. It is known that this oddity can be circumvented by combining scale categories (Williams 2006b). Hence, we utilized both the stereotype and multinomial logit models to identify which scale categories are nondistinguishable and thus should be combined. This procedure has two advantages: first, by ensuring that the categories of our dependent variable are distinct, we ensure a condition for valid estimates (estimates for non-distinct categories cannot be valid); and, second, a common dependent variable enables comparison between our two preferred approaches to estimation.

\section{Independent variables}

Innovation performance, as a dependent variable measured by innovative sales, is a function ( $f$ ) of absorptive capacity, firm characteristics, environmental (external) factors and open innovation practices (Eq. 1).

Innovative sales $=f$ (absorptive capacity, firm characteristics, environmental factors, inbound open innovation practices)

Our model from Equation 1 is presented as a conceptual model in Figure 1 below.

Absorptive capacity. A necessary pre-condition for undertaking inbound open innovation is the development of firms' internal capacity for absorbing and exploiting knowledge (that is, absorptive capacity) (Cohen and Levinthal 1990; Laursen and Salter 2006; Spithoven,Clarysse, and Knockaert 2010). Firms' absorptive capacity is usually measured by internal R\&D activities, proxied by several measures: internal (intramural) $R \& D$ expenditures; the share of $R \& D$ personnel; and the presence of a separate R\&D department (Cassiman and Veugeler 2002; Faems et al. 2010; Muscio 2007; Spithoven, Clarysse, and Knockaert 2010). The dataset contains information on the two latter measures, which are included in the model. ${ }^{3}$ The share of $\mathrm{R} \& \mathrm{D}$ personnel ( $R \& D$ personnel) in the

\footnotetext{
${ }^{3}$ The dataset used in the analysis contains information about the share of innovation expenditure in total expenditure, but innovation expenditure encompasses both internal and external (extramural) R\&D expenditures. Given that outsourcing $R \& D$ is considered as a type of open innovation, the share of innovation
} 
total number of employees is a categorical variable, while having a separate $\mathrm{R} \& \mathrm{D}$ department $(R \& D$ department $)$ is measured as a binary variable $(=1$ if a firm has a separate $R \& D$ department; 0 otherwise).

Figure 1. A conceptual model of the relationship between the independent variables and the dependent variable.

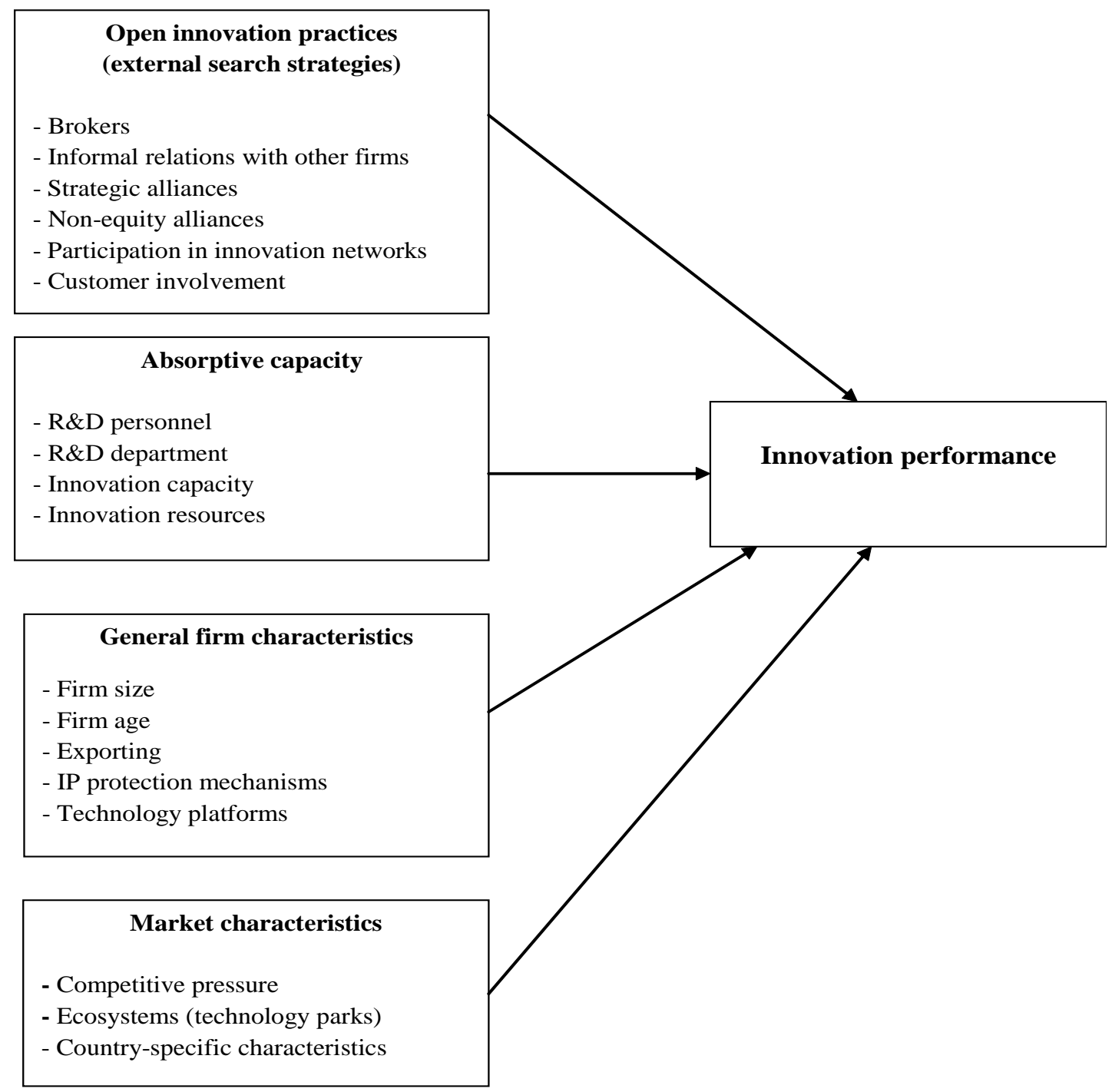

Furthermore, our model includes two variables that measure firm-level "quasi fixed effects" or initial conditions (Blundell, Griffith, and Van Reenan 1995; for recent applications to innovation models, see Radicic et al., 2015; Czarnitzki and Delanote 2015). These initial conditions control for measuring the share of $R \& D$ personnel (the correlation coefficient is 0.79 ), suggesting a potential problem with multicollinearity if both variables were to enter the model (Greene 2005). 
firms' time invariant unobserved effects on innovation, including firms' innovative capacity at the beginning of the period covered by the survey. Firms' quasi fixed effects are modelled with two dummy variables. The variable Resources measures the resources invested in innovation in 2005 relative to 2009 (DV=1 if the firm's response to the question "Five years ago did you devote?" was 'Fewer resources to innovation'; = 0 if 'About the same' or 'More'). The variable Innovation capacity measures the firms' innovation capacities within the industry in 2005 (DV=1 for 'Above average' and 'Leading'; =0 for 'Average' and 'Lagging') (see Appendix Table A1 for variable definitions).

Firm characteristics. The firm's degree of internationalization (Export) is modelled by including a binary indicator that is equal to 1 if the firm undertakes exporting activities. Exporting firms tend to have more incentive to innovate as a result of competitive pressure on international markets (Parida, Westerberg, and Frishammar 2012). To control for firm size, three binary indicators were created: for micro firms; small firms; and medium-sized firms (micro firms are the base category). The model also includes firm age (Age) as a continuous variable (in natural logarithms). A stylised fact regarding the relationship between firm age and innovation performance is that younger firms tend to be more innovative (Parida,Westerberg, and Frishammar 2012).

In addition, we control for the formal mechanisms of Intellectual Property (IP) protection. The variable IP_protection is constructed as the average score of three protection mechanisms (measured as binary indicators): patents acquired in the EU; patents acquired in the US; and acquired trademarks $($ Cronbach's alpha $=0.63)($ see, for instance, Ebersberger et al. 2012; Spithoven, Vanhaverbeke, and Roijakkers 2013). Due to their limited financial and human resources, the literature suggests that SMEs engage in informal protection mechanisms (such as secrecy and speed to market) to a larger extent than in formal protection mechanisms (such as patents and other IPs) (Kitching and Blackburn 1998; Leiponen and Byma 2009). However, that does not mean that using formal IPs is not beneficial for the commercial success of product and process innovation in SMEs. Spithoven, Vanhaverbeke, and Roijakkers (2013) argue that SMEs patent only those inventions that are likely to result in a successful commercialization of innovation, unlike large firms that usually have established IP departments and routinely patent their inventions. These different patenting strategies reflect the varying degree of financial resources available to businesses. In this context, 
SMEs, constrained by limited financial resources, will apply for patents to a significantly lower extent than will large firms. However, as SMEs use patents strategically, focusing on the market potential of the patented inventions, the performance impact of patenting activities is potentially larger in SMEs. Moreover, assuming that financial constraints gradually decline as firm size increases, medium-sized firms could be more inclined to file patents than would be either small or micro firms. This proposition is partially supported by our data: 23.6 per cent of the medium firms applied for formal IP protection mechanisms; 22.8 per cent of small firms; and 14.5 per cent of the micros (where the differences between micro and small and micro and medium are statistically significant at conventional levels, although the difference between small and medium is not). However, the weaker resource constraints and correspondingly greater propensity to seek formal IP protection means that medium size firms will implement a higher proportion of their potentially successful patents than will the more resource constrained small and micro firms. In this case, diminishing returns again suggest greater commercial returns to additional patents for the more constrained micro and small firms than for the less constrained medium firms.

Environmental factors. The model also takes into account environmental factors, such as competitive pressure, industry characteristics, whether firms operate in technology parks and whether they integrate cluster/technology platforms. Competitive intensity (Competition) is measured as a binary indicator equal to 1 if the firm reports that the competition is strong in its main markets $(0$ otherwise). Furthermore, to control for firms' technological environment, two binary indicators were included for those firms that are located in technology parks and for those that integrate cluster/technology platforms (Technology park and Technology platform respectively). Sectoral heterogeneity is taken into account by creating six industry categories using the OECD taxonomy: high tech; medium high tech; medium low tech; low tech; Information and Communication Technology (ICT); and service sectors (as the base category). Manufacturing industries are grouped based on the NACE classification according to technology intensity (OECD 2006). Finally, the models include binary indicators for three country groups: 'Innovation leaders'; 'Moderate innovators'; and 'Modest innovators' ('Innovation followers' is the base category). 
Open innovation practices. Search strategies are modelled by including seven variables for, respectively, each source of knowledge identified in the survey questionnaire (see below). External sources of knowledge encompass the following categories: 1) use of online technology or knowledge brokers/intermediaries (Source_brokers); 2) informal networking with other firms (Source_other_firms); 3) informal networking with research organizations (Source_research); 4) strategic alliances with other firms (Source_strategic); 5) non-equity alliances with other firms (Source_non_equity); 6) participation in innovation networks, S\&T parks and clusters (Source_networks); and 7) close involvement of end users/customers in idea generation/concept development (Source_customers). Each source of external knowledge is measured on a five-point scale (from 'Do not apply at all' to 'Apply extensively'). Based on this scale, categorical variables were created for each source of external knowledge (see Appendix Table A1).

Descriptive statistics are reported in Appendix Table A1 for all firms, by firm size category and by industry. The correlation matrix showing the Pearson correlation coefficients among the independent variables is presented in Appendix Tables A2 and A3. The correlations are overall low to moderate suggesting that multicollinearity is unlikely to occur.

\section{Estimation strategy}

Our dependent variable has four outcomes; namely, successively higher ranges of innovative sales. In this section we explain our choice of model to estimate the effects of our variables of interest together with a wide range of control variables on the probabilities of these different innovation outcomes. Neither probit nor logit estimation is appropriate, because our dependent variable has more than two categories. We also reject both ordered probit and ordered logit as our sole approach, because neither addresses failure of the parallel regression assumption.

Diagnostic testing for non-linear models is still not much developed (UCLA, 2015a), and this includes the lack of any established procedure for choosing between models. One diagnostic procedure available to researchers (Wooldridge, 2010, p.658) is testing the proportional odds assumption (also known as the parallel regression assumption). This assumption posits that the slope coefficients are identical across all categories of the dependent variable (i.e. all outcomes) (Long and 
Freese 2001, p.150). According to Long and Freese (2001, p.152), this assumption is often violated, while Williams (2006a) suggests that common practice is to ignore the violation of the proportional odds assumption and report the estimates of the ordered logit model, which are then incorrect or misleading. For some of our models, both the likelihood ratio test developed by Wolfe and Gould (1998) and the Wald test (also known as the Brant test, after Brant 1990) indicate that the proportional odds assumption can be rejected at the 1 per cent level.

The multinomial logit model does not require the proportional odds assumption (Long and Freese 2001, p.169). Yet, our dependent variable has a natural ordering, from low to high proportions of innovative sales. Accordingly, to avoid loss of information, we do not apply the multinomial logit model, which entails treating our ordered dependent variable as nominal.

Based on validation or relaxation of the proportional odds assumption, three models are candidates to estimate the effects of our variables of interest together with a wide range of control variables on the probabilities of the different innovation outcomes (Williams 2006; Soon 2010). When the proportional odds assumption is not rejected, the proportional odds model (that is, the ordered logit model) is appropriate, because it restricts the estimated effects to be the same across all innovation outcome categories. ${ }^{4}$ Conversely, when the proportional odds assumption is rejected, there are two contenders.

1. The generalized partial proportional odds model relaxes the proportional odds assumption only for those covariates for which the assumption does not hold. For these covariates, the estimated coefficients are allowed to vary across successively higher levels of innovation outcomes. Conversely, for those covariates that do not violate the proportional odds assumption, the estimated coefficients are restricted to be the same across the innovation outcomes.

2. The generalized logit model relaxes the proportional odds assumption for all innovation outcomes and is thus the least restrictive model.

\footnotetext{
${ }^{4}$ If the proportional odds assumption is not rejected then either ordered logit or ordered probit are appropriate. However, these yield qualitatively similar results. Ordered logit is chosen to be consistent with the partial proportional odds model, our preferred estimator when the proportional odds assumption is rejected.
} 
Of these two, we chose the generalized partial proportional odds model (Clogg and Shihadeh 1994; Fu 1998), which as well as allowing us to take into account the ordinal nature of our data has several additional advantages: Williams (2006a) stresses that compared both to the multinomial logit model and to the generalized proportional odds/parallel-lines model the generalized partial proportional odds model is both more interpretable and more parsimonious, with the consequent estimation of fewer parameters yielding an efficiency gain. Unlike the multinomial logit model and the generalized proportional odds/parallel-lines models, the partial proportional odds model takes into account that, for some variables, the proportional odds assumption may not be rejected and, consequently, relaxes this assumption only for those variables that violate it (hence the term "partial"). Given a relatively small dataset, this is a relevant consideration for our analysis, as an increased number of parameters might render some estimates statistically insignificant (Williams 2006a). Accordingly, we report results from two models, according to whether or not the proportional odds assumption holds: ordered logit when this assumption holds; and the generalized partial proportional odds model when it does not.

The interpretation of the category-specific coefficients estimated by the generalized partial proportional odds model is as follows: the first column in each results table contrasts category 1 (innovative sales 0-10\%) with categories 2 (innovative sales 11-30\%), 3 (innovative sales $31-50 \%$ ) and 4 (innovative sales $>50 \%$ ); the second column contrasts categories 1 and 2 with categories 3 and 4; and the third column contrasts categories 1, 2 and 3 with category 4 (Williams 2006a). The proportional odds assumption of ordered logit means that each statistically significant estimated coefficient suggests a single positive/negative effect related to the probability (ceteris paribus) of placing a firm in a higher/lower category of innovative sales whatever its actual proportion of innovative sales. ${ }^{5}$ In contrast, the unrestricted estimates of the partial proportional odds model allow a firm's actual position with respect to innovative sales to condition its response to each independent variable. For example, in Table 1, the effect of using customers as a source of information (Source_customers) has a larger effect on the probability of achieving higher levels of innovative

\footnotetext{
${ }^{5}$ The "standard interpretation of the ordered logit coefficient" (UCLA, 2015b)is that "for a one unit increase in the predictor, the response variable level is expected to change by its respective regression coefficient in the ordered log-odds scale while the other variables in the model are held constant."
} 
sales for firms in the lowest category of innovative sales - 0-10\% - than for firms in the three higher categories (0.551); a somewhat smaller effect on firms when the next highest category $->30 \%$ - is added (0.305); and the smallest effect when the third highest category ->50\% - is added (0.219).

\section{Results}

In this section, we report detailed findings from all eight models, respectively estimated from: the overall sample; three categories of firms' size; and four sectors (high-tech, low-tech, ICT and service firms). This will facilitate comparison with cognate studies. In the Discussion section (below), we focus more precisely on our formulated hypotheses together with other topics suggested by our review of the literature.

Concerning the results for the full sample of SMEs (see Table 1), we first focus on the variables of interest measuring OI practices. A positive and statistically significant coefficient on using customers as a source of knowledge (Source_customers) suggests that an increase in the use of customers as a knowledge source increases the probability of higher innovative sales. In contrast, participation in innovation networks as a knowledge source (Source_networks) increases the likelihood of lower innovative sales, i.e. decreases firms' innovativeness. ${ }^{6}$ Looking at control variables, IP protection is positively associated with higher innovative sales. Furthermore, absorptive capacity plays a significant role in the commercial success of innovation, as coefficients on both

\footnotetext{
${ }^{6}$ Using the whole sample, we also tested whether participation in innovation networks moderates the impact of other OI practices on innovation performance, as recently suggested by Mazzola, Perrone, and Kamuriwo (2015). We would like to thank an anonymous referee for this suggestion. This hypothesis is tested by augmenting our model with six interaction variables calculated by multiplying each of our six variables representing other sources of external knowledge with the variable representing participation in innovation networks (Source_networks) as a knowledge source. Due to multicollinearity, each of these interactions proved to be statistically insignificant at any conventional level. Accordingly, we entered each interaction term individually. The coefficients on two of these interaction terms (informal network with research organization Source_research - moderated by participation in innovation networks; and strategic alliances Source_strategic - moderated by participation in innovation networks) proved to be negative and statistically significant at the 5 per cent level in the highest category of innovative sales. These two significant interactions suggest that Source_networks exerts an indirectly negative effect on SME innovation when combined with either Source_research or Source_strategic. Of course, this suggestion is tentative, because it is based on only two results from six (i.e. two interaction effects on each of three categories of innovative sales). To this extent, this result conflicts with the positive interactions reported by Mazzola, Perrone, and Kamuriwo (2015), although their findings refer to aggregate measures of open innovation whereas ours refer to individual OI practices.
} 
variables $R \& D$ personnel and $R \& D$ department are positive and statistically significant (at the $1 \%$ and $10 \%$ levels respectively). Conversely, older firms are less innovative than their younger counterparts, but this result holds for only those firms with innovative sales more than $30 \%$. Finally, integrating technology platforms marginally increases the likelihood of commercial success from innovation. Although we control for firm size, as well as for industry and country heterogeneity, we do not interpret these results, in particular, because our further analysis is focused on firm size categories and industry division based on technology level.

\section{>> Table 1 here $<<$}

Table 1 also reports results for micro firms with fewer than 10 employees. Again, we first interpret results for the variables of interest. Using customers as a knowledge source (Source_customers) would increase innovativeness, but only in less innovative firms (innovative sales from 0-10\%). In addition, using other firms (Source_other_firms) and participating in strategic alliances (Source_strategic) increase innovation performance of firms in the middle category, while knowledge brokers (Source_brokers) strongly adversely affect the innovative performance of these firms. Participation in innovation networks (Source_networks) negatively affects the commercial success of all but highly innovative firms. Focusing on absorptive capacity, increasing the share of R\&D personnel positively and highly significantly affects both less innovating firms and highly innovating firms, with no effect on the middle level of innovation performance. Regarding other control variables, an increase in IP protection increases firms' innovativeness, but only for firms that are already highly innovative (innovative sales above 50\%). Exporting activities reduce the commercial success of less innovative firms, with no impact on highly innovative firms. The impact of firm age on innovation performance depends on the level of innovativeness; compared to their younger counterparts, older less innovative firms are more innovative, whereas older more innovative firms are less innovative. Similar effects are reported for competitive pressure; higher pressure increases innovation performance of less innovative firms but reduces the innovativeness of more innovative firms. Firms' past innovation capacity has a significant positive impact only on firms at the middle level of innovation performance. Likewise, location in a technology park increases the proportion of innovative sales only for firms at the middle level of innovativeness. 
The estimates for small and medium firms are from ordered logit, as the proportional odds assumption was not violated in these subsamples (Table 2). Customer involvement in the innovation process (Source_customers) positively and highly significantly affects innovation performance of small firms. Again, some OI practices are not beneficial for the commercial success of innovation. Namely, for small firms, using innovation networks as a source of knowledge (Source_networks) decreases innovation performance. With respect to control variables, absorptive capacity proxied by the firm having an $\mathrm{R} \& \mathrm{D}$ department is important for innovation performance, but only marginally (at the $10 \%$ level), while older firms are less innovative than younger small firms. An increase in the number of IP mechanisms of protection has a positive and highly significant performance effect.

\section{>> Table 2 here $<<$}

The final firm size category is medium firms (Table 2). Here, the only OI practice that positively affects innovation performance is customer involvement (Source_customers). In contrast, using other firms as a knowledge source (Source_other_firms) decreases innovative sales in medium firms. Focusing on control variables, absorptive capacity proxied by R\&D personnel and by resources devoted to innovation positively affects innovation performance.

The next set of results is reported for subsamples of firms operating in different sectors. Table 2 reports the results for firms in the ICT and service sectors. These models are estimated by the ordered logit model, because the proportional odds assumption holds in these models. In addition, following Grimpe and Sofka (2009), we grouped manufacturing industries into two categories: hightech and medium-high-technology; and low and medium-low-technology industries (see Table 3 for both models). These models are estimated by the generalized partial proportional odds model as the proportional odds assumption only partially holds in these subsamples.

Firms operating in the ICT sector (Table 2) experience positive performance effects by using external knowledge from other firms other than customers (Source_other_firms). However, other sources of external knowledge have no impact on innovative sales. Concerning control variables, firms with a higher share of R\&D personnel are more innovative, and this effect is highly statistically 
significant (at the one per cent level). In contrast, IP protection is not associated with higher innovative sales.

In relation to the service sector (Table 2), our results suggest no impact of external search strategies on innovation performance. Conversely, protection of IP has a positive and significant impact on innovative sales (at the $1 \%$ level). We can assume that this result is associated with the importance of trade marks in the service sector, given that the variable IP_protection is a composite construct including not only patent application, but also trademarks. Blind et al. (2003, p. 17) found that firms' self-reported trademarks are their most important protection mechanism. Moreover, Hipp and Grupp (2005) suggest trademarks as a new measure of service innovations. Looking at other control variables, measures of absorptive capacity do not have performance effects, which is in line with expectations. Namely, empirical measures of absorptive capacity usually capture R\&D activities, which are not a common source of innovation in service sectors (Hipp and Grupp2005; Mina, Bascavusoglu-Moreau, and Hughes 2014). In contrast, firms in the service sectors rely more on intangible assets, such as organizational and human resources (Gallouj and Savona 2009; Hipp and Grupp 2005; Mina, Bascavusoglu-Moreau, and Hughes 2014). However, it is interesting to note that both past innovation capacity and innovation resources have a positive impact on firms' innovativeness. As these variables in our study encompass not only past $R \& D$ but other, non-R\&D innovation activities and influences, this finding could suggest two conclusions. First, SMEs in the service sector are innovative, although not in a traditional way, reflected in formal R\&D activities, but in a broader sense, including other sources of innovation (Mina, Bascavusoglu-Moreau, and Hughes 2014). Second, past innovative capacity, including intangible assets, positively affects the current commercial success of innovation.

Table 3 reports estimates for high-technology SMEs. Using other firms as knowledge sources (Source_other_firms) marginally decreases firms' innovation performance. Moreover, research institutions (Source_research) and strategic alliances (Source_strategic) have a highly significant impact at the middle level of innovativeness, while participation in innovation networks (Source_networks) has an adverse performance effect. The performance effect of customer involvement (Source_customers) is heterogeneous; only less innovative firms can benefit from this 
source of knowledge, while firms at the middle level of innovativeness experience a strong negative effect. An increase in the share of R\&D personnel increases innovation performance of highly innovative firms, while established R\&D departments marginally increase innovation performance at all levels of innovativeness. The latter corroborate the findings from Vega-Jurado,Gutiérrez-Gracia, and Fernández-de-Lucio (2009), who also report a positive performance effect of continuous R\&D activities in Spanish high-tech firms. Past innovation capacity has a positive effect at the middle level of innovation performance, but past innovation resources reduce the innovation performance of highly innovative firms, indicating that these firms might experience a lock-in effect or competence trap (Levitt and March 1988). Firm age has a varying performance effect. Compared to their younger counterparts, older less innovative firms are more innovative, but older more innovative firms are less innovative.

\section{>> Table 3 here $<<$}

Finally, Table 3 also presents results for low-technology SMEs. The literature on open innovation suggests that SMEs in low technology sectors, although engaging less in formal R\&D activities than their counterparts in high-tech industries (evidenced, for instance, by the absence of formal R\&D departments), still open up their innovation processes (Muscio 2007; Spithoven, Clarysse, and Knockaert 2010). Yet, SMEs in low-tech industries are characterized by a low level of absorptive capacity, where our measure of absorptive capacity is defined in terms of R\&D (Muscio 2007; Spithoven, Clarysse, and Knockaert 2010). Using online technology and knowledge brokers (Source_brokers) adversely affects innovation output, while informal networking with other research organizations (Source_research) is positively associated with innovation performance. Using nonequity alliances (Source_non_equity) increases the innovativeness of SMEs in the middle category, but participation in innovation networks (Source_networks) decreases innovation performance of the firms in this category of innovation outcome. Using customers as a source of knowledge (Source_customers) increases the innovation performance of low and medium innovative firms, but has no effect on more innovative firms. Concerning other control variables, IP protection increases firms' innovation performance, irrespective of their level of innovative sales. Exporting is positively 
associated with innovation performance in less innovative SMEs, but also in more innovative firms. Older innovative firms are less innovative than their younger counterparts. Having an established R\&D department decreases the innovativeness of SMEs with the lowest level of innovative sales, but increases the innovativeness of other, more innovative SMEs (perhaps reflecting the differential effectiveness of R\&D in less and more innovative SMEs). In contrast, the results also suggest that past innovation capacity increases the commercial success of innovation, regardless of the level of innovativeness. Finally, integrating a technology platform is positively associated with medium and high categories of innovative sales.

\section{Discussion}

To allow patterns to be perceived and discussed, we compress our extensive findings into Table 4, which identifies the statistically significant positive (+) and negative (-) estimates.

\section{> Table 4 here $<<$}

We now discuss our findings in accord with the hypotheses set out above.

Hypothesis 1. Our main hypothesis focuses on the general impact of OI practices on innovative sales. Overall, our findings contribute to the literature by supplementing Spithoven, Vanhaverbeke and Roijakkers (2013) who report no significant effect on innovative sales from aggregate external search strategies (see their Table 3). In contrast, we report differentiated effects from seven such individual search strategies (OI practices). Across the SME size categories, only two OI practices display systematic effects: participation in innovation networks (Source_networks) and customer involvement (Source_customers). However, there is insufficient evidence to suggest any relationship between the effects of either of these OI practices and the size of SMEs. Considering SMEs categorised by sector, there are other noteworthy effects: the use of knowledge brokers (Source_brokers) leads to negative outcomes for low-tech firms but not for high-tech firms; use of other firms (i.e. other than customers) (Source_other_firms) leads to negative outcomes for high-tech firms but not for low-tech firms; and use of research organizations (Source_research) leads to positive outcomes for both high- and low-tech firms. Overall, our findings suggest: (1) a range of OI effects on SME innovation performance, both positive and negative; and (2) no relationship between these 
effects and firm size. Variation in OI effects by sector suggests the need for theory development to inform further research.

Hypothesis 2. For most of our SME categories, the use of knowledge brokers (Source_brokers) has no effect. Where there is evidence of an effect, it is negative. This finding should be considered in the light of Katila and Ahuja (2002) and Hsu and Lim (2013), who find that the performance effects of knowledge brokers is non-linear - rising then falling with the number of brokers - which is a possibility beyond the range of our data.

Hypothesis 3. Competing theories suggest opposing possibilities for the effects of informal networking with other firms (Source_other_firms). Our estimates suggest that these theories may be more or less applicable to different types of SME: positive estimates suggest that some micro firms (those with intermediate levels of innovative sales) and ICT firms may benefit from the low cost and flexibility of trust relationships; while negative estimates suggest that high-tech firms have more to fear from knowledge leakages.

Hypothesis 4. We find that the effect of informal networking with research organisations on SME innovation performance does not vary with firm size (Source_research). Yet such networking does yield positive innovation effects for some high-tech firms (those with intermediate levels of innovative sales) and for all low-tech firms. This is consistent with the literature as well as with the presumption that low-tech firms have less in-house capacity for research and correspondingly greater need for external knowledge sources. (In our sample, compared to low-tech SMEs, high-tech SMEs are much more likely to have an $\mathrm{R} \& \mathrm{D}$ department and to have much higher percentages of employees engaged in R\&D; see Appendix, Table A1.)

Hypothesis 5. While the innovation effects of formal alliances - Source_strategic and Source_non_equity - are positive, and thus in accord with the literature, we have too few estimates to infer patterns of variation between either SME size categories or sectors.

Hypothesis 6. Sourcing external knowledge from participation in innovation networks (Source_networks) displays a detrimental innovation effect across the whole sample as well as for most micro firms, small firms and for single categories of both high- and low-tech firms (8 from 16 estimates). This is consistent with alternative explanations: on the one hand, the assumption, as 
previously noted, that SMEs face the risk of negative knowledge spillovers, due to knowledge leakage and opportunistic behaviour of competitors; on the other, adverse lock-in effects are a possibility. ${ }^{7}$

Adverse consequences from participation in innovation networks arising from knowledge leakage and opportunistic behaviour by network partners are consistent with the positive effects of formal protection mechanisms on SME innovation performance (IP protection) identified below.

Hypothesis 7. The outstanding finding is that customer involvement (Source_customers) is positively associated with innovation performance ( 9 from 10 significant estimates): this effect pertains in all the whole sample estimates and, in particular, for the least innovative micro firms, small firms, medium firms, the least innovative high-tech firms and two of the three innovation categories of low-tech firms. This result is in line with the theoretical argument on open innovation in SMEs, as previously noted, that SMEs mostly undertake user innovation. This argument has been most recently empirically confirmed in Brunswicker and Vanhaverbeke (2014), who report a positive association between application-oriented sourcing (mainly focusing on customer involvement) and SME innovation performance. The evidence suggests that, relative to other firms, the least innovative and low-tech firms are more dependent on customer involvement to initiate innovation activity.

Finally, we comment on those control variables that prove to be significant influences in half or more of our models. From the 16 reported estimates of the effects of formal protection mechanisms on SME innovation performance (IP protection), all 9 significant estimates are positive. In particular, highly innovative micro firms, small firms, low-tech firms and service firms that use formal protection mechanisms are more likely to realize higher innovative sales. Of the non-significant estimates, all but one are positive. This evidence does suggest that IP protection is positively associated with innovation performance in SMEs. This finding supports similar findings reported in Spithoven, Vanhaverbeke, and Roijakkers (2013). Regarding sectoral analysis, we find positive effects of IP protection in low-tech and service sectors, but no statistically significant effects in hightech and ICT sectors, which is consistent with Kim and Park (2010). This result should be taken in conjunction with the much greater propensity of high-tech firms to undertake IP protection than is the

\footnotetext{
${ }^{7}$ In footnote 6, we tentatively advance evidence suggesting that Source_networks also exerts an indirectly negative effect when it accompanies other external search strategies, by diminishing their effects.
} 
case for firms in any other sector (see Appendix Table A1; see also: Leiponen and Byme 2009;

Spithoven, Vanhaverbeke, and Roijakkers 2013). Accordingly, our findings may reflect the logic of diminishing returns, such that high-tech firms using formal IP protection routinely may find it less effective at the margin than do low-tech firms making relatively occasional use of IP protection. However, this can be no more than a tentative suggestion, given that the service firms in our sample have a slightly greater propensity to use IP protection than do the ICT firms. In addition, trademarks (which are included in our measure of IP protection) are important protection mechanisms in both low-tech sectors (Greenhalgh and Longland 2005) and service sectors (Blind et al. 2003, p. 17; Hipp and Grupp 2005). Our findings indicate their positive performance effects on SMEs in these sectors. As we anticipate, the empirical results are conclusive regarding the positive impact of firms' absorptive capacity on their innovation performance (from our 8 models, 7 have at least one significant proxy for absorptive capacity). In this respect, our findings corroborate the conclusion by Brunswicker and Vanhaverbeke (2014) on the key role of absorptive capacity in adopting OI practices by SMEs. Moreover, these findings are consistent with the stylised fact advanced in the wider innovation literature on the importance of absorptive capacity; namely, that opening up the innovation process by exploiting sources of external knowledge is a complementary process to firms' absorptive capacity (Chesbrough and Crowther 2006; Cohen and Levinthal 1990; Dahlander and Gann 2010; Schroll and Mild 2011; Spithoven, Clarysse, and Knockaert 2010; Vega-Jurado, Gutiérrez-Gracia, and Fernández-de-Lucio 2009).

In addition, our findings on two further control variables are noteworthy. Firm age is a standard control variable in innovation models, and as expected appears in our models with a mainly but not exclusively negative effect ( 6 from 8 estimates), suggesting that younger firms are more innovative. Finally, we note that in five of the eight models, one or both of our quasi-fixed effects are positively associated with firms' innovation performance, thereby suggesting their value as control variables. 


\section{Conclusions}

This study explores how open innovation strategies affect innovation performance in SMEs across Europe. Although recently more studies have focused on OI in SMEs, there is still little empirical evidence on the performance effects of OI strategies in these firms (Brunswicker and Vanhaverbeke 2014). There is even less empirical evidence on the relationship between innovation success and OI practices in particular firm size categories (Spithoven, Vanhaverbeke, and Roijakkers 2013). We make a modest theoretical suggestion as to why we might expect such a relationship. Namely, we argue that the smaller the firm, the greater the relative resource constraints and the smaller the corresponding proportion of potential OI activities implemented, a corollary of which allowing for diminishing returns - is that the smaller the firm the higher the returns to OI activities. Accordingly, our study takes into account the heterogeneity of SMEs by exploring performance effects of OI practices not only in the whole sample of SMEs but also in subsamples by size. We also explore sector subsamples.

We use new survey data to estimate eight models, four of which allow different levels of innovative sales within categories of firms. There are three notable features of our empirical strategy. First, we use a pre-testing procedure to establish the number of independent categories in our dependent variable. Secondly, testing the parallel regression assumption guides our choice between ordered logit and partial proportional odds estimation. Thirdly, we specify our models to include initial conditions, which within a cross-section context introduce time invariant "quasi fixed effects" and thus control for otherwise unobserved heterogeneity.

We conclude that our results are broadly supportive of the theoretical framework of OI advanced by Huang and Rice (2009): other factor held constant, we find that firms increase their innovative sales intensity by engaging with certain types of knowledge sources (especially customers and research organizations) but desisting from others (innovation networks and knowledge brokers) while protecting their IP and enhancing their absorptive capacity.

The findings provide implications for managers, who are responsible for developing and implementing open innovation strategies: 
- nearly all types of SMEs may enhance the commercial success of innovation by using customers as a source of knowledge;

- most types of SMEs may enhance the commercial success of innovation by maintaining absorptive capacity through in-house innovation activities; and

- SME owners and managers might like to exercise particular caution when considering innovation networks as a source of knowledge, particularly with respect to the protection of IP.

Furthermore, our empirical evidence reveals heterogeneity in the performance effects of search strategies in different sectors. Firms in high-tech and low-tech industries seem to benefit more from search strategies than do firms in the ICT and service industries. However, some search strategies have an adverse performance effect in firms in high-tech and low-tech industries. We posit that the negative effects are related to inadequate protection of IPs stemming from knowledge leakage and opportunistic behaviour of partners. Namely, the negative performance effects are associated with using other firms (other than customers) and networks. In contrast, IP protection has uniformly positive innovation effects.

Finally, we can also provide recommendations for policy makers. First, in promoting open innovation among SMEs, policy makers should take into account their firm and sectoral characteristics. SMEs are not a homogeneous group of firms and performance effects of OI practices differ across categories. Thus, "one-size-fits-all" policy measures aimed at promoting SME open innovation are less likely to provide optimal outcomes than are demand-led measures. This conclusion is consistent with a recent trend in EU innovation policy (Edler et al. 2012).

\section{Limitations and future research}

This study on the performance effects of open innovation strategies among European SMEs is subject to a number of limitations, which can serve as points of departure for further research. First, the sample size is too small to identify the impact of open innovation on SMEs at the country level. Secondly, the size of our subsamples varies, which may affect reported levels of statistical significance and so comparisons of estimates between our subsamples. For example, our firm-size 
subsamples vary as follows: micro (304); small (200); and medium-sized (116). However, Table 4 does not suggest that our main conclusions are driven by the ability of larger (smaller) samples to yield more (less) precise estimates. For example, although we find that IP protection has no significant performance effect on medium firms, we do find a significant effect for service firms estimated from a similar sized sample (118 firms). Conversely we find significant Source_customer effects for all three size categories. Thirdly, our data is cross-sectional, which means we are unable to say anything about the dynamics of the innovation process, in particular how accessing external knowledge acts on innovation performance over time. Availability of panel data would allow investigation of the persistence of knowledge sourcing and, hence, of its medium- to long-run effects (Mazzola, Bruccoleri, and Perrone 2012). Fourthly, our findings for the service sector may reflect the lack of a service-specific measure of innovation output. Namely, product and process innovations and their commercial success proxied by innovative sales cannot adequately measure service innovation (Mina, Bascavusoglu-Moreau, and Hughes 2014). Other, non-technological innovations, such as organizational and marketing innovations, besides service innovation may be better-suited measures of innovation performance in the service sector (Hipp and Grupp 2005). Second, the service sector is characterized by diversity between and within individual service sectors (Hipp and Grupp 2005; Mina, Bascavusoglu-Moreau, and Hughes 2014). Because of our relatively small subsample of SMEs in the service sector, we are unable to further develop our analysis, by, for instance, looking at the knowledge-intensive services. Partly for this reason, future studies could explore the impact of knowledge flows on other measures of innovation output, such as the introduction of technological product and process innovations as well as non-technological organizational and marketing innovations. Fifthly, our data does not allow a distinction between radical innovation, usually proxied by the share of sales from products new to the market, and incremental innovation measured as the share of sales from products new (or significantly improved) to the firm (see, for example, Laursen and Salter 2006). In this respect, Laursen and Salter (2006) found a significant impact of lead users as a knowledge source on both categories of innovation. Finally, future studies might investigate how search breadth (number of knowledge sources) and depth (intensity of use of knowledge sources) affect innovation performance of SMEs and whether their relationship is curvilinear, as first reported 
in Laursen and Salter (2006). Namely, for some firm size categories, in particular micro firms,

increasing OI practices might have a positive performance effect to a certain point, after which the

returns become negative due to over-search. This inverted-U shaped relationship would suggest that

externalizing absorptive capacity initially has a positive effect, which turns into a negative effect

when the limit of absorptive capacity is reached.

\section{References}

Acs, Z.J., and D.B. Audretsch (1988). "Innovation in large and small firms: An empirical analysis," The American Economic Review 78(4), 678-690.

Anderson, J. A. (1984). "Regression and ordered categorical variables (with discussion),"Journal of the Royal Statistical Society Series B 46, 1-30.

Bahemia, H., and B. Squire (2012)."Managing Open Innovation in New Product Development Projects: A Contingent Perspective," In: Perspectives On Supplier Innovation: Theories, Concepts And Empirical Insights On Open Innovation And The Integration Of Suppliers. Ed. A.Brem and J. Tidd. London: Imperial College Press, 95-128.

Bascavusoglu-Moreau, E., A. Mina, and A. Hughes (2013)." Exploiting Knowledge Flows: Openness and the innovative performance of business services," paper presented at the DRUID conference.

Bianchi, M., S.C. Orto, F. Frattini, and P. Vercesi (2010)."Enabling Open Innovation in Small- and Medium-Sized Enterprises: How to Find Alternative Applications for Your Technologies," $R \& D$ Management 40(4), 414-430.

Blind, K., J. Edler, U. Schmoch, B. Andersen, J. Howells, I. Miles, J. Roberts, L. Green, R. Evangelista, C. Hipp, and C. Herstatt (2003)."Patents in the service industries," final report prepared for the European Commission, Fraunhofer ISI, Karlsruhe, EUR 20815.

Blundell, R., R. Griffith, and J. Van Reenan (1995). "Dynamic Count Data Models of Technological Innovation," Economic Journal 105(429), 333-344.

Bogers, M. (2011)."The open innovation paradox: Knowledge sharing and protection in R\&D collaborations," European Journal of Innovation Management 14(1), 93-117.

Boschma, R. (2005). "Proximity and innovation: a critical assessment," Regional Studies 39 (1), 61 74.

Brant, R. (1990). "Assessing proportionality in the proportional odds model for ordinal logistic regression," Biometrics 46(4), 1171-1178.

Brunswicker, S., and W. Vanhaverbeke (2014). "Open Innovation in Small and Medium-Sized Enterprises (SMEs): External Knowledge Sourcing Strategies and Internal Organizational Facilitators," Journal of Small Business Management, DOI: 10.1111/jsbm.12120.

Cassiman, B. and R. Veugelers (2002)."R\&D cooperation and spillovers: Some empirical evidence from Belgium," American Economic Review 92(4), 1169-1184.

Chesbrough, H. (2003). Open innovation: The new imperative for creating and profiting from technology. Boston: Harvard Business School Press.

Chesbrough, H., and A.K. Crowther (2006). "Beyond high-tech: early adopters of open innovation in other industries," R\&D Management 36(3), 229-236. 
Chesbrough, H., W. Vanhaverbeke, and J. West (2006). Open innovation: Researching a new paradigm. London: Oxford University Press.

Chesbrough, H. (2011). Open Service Innovation: Rethinking Your Business to Grow and Compete in a New Era, San Francisco: Jossey Bass.

Chiaroni, D., V. Chiesa, and F. Frattini (2011)."The Open Innovation Journey: How firms dynamically implement the emerging innovation management paradigm," Technovation 31(1), 34-43.

Clarysse, B., M. Wright, and P. Mustare (2009)."Behavioural additionality of R\&D subsidies: A learning perspective," Research Policy 38(10), 1517-1533.

Clogg, C. C., and E. S. Shihadeh (1994). Statistical Models for Ordinal Variables. Thousand Oaks, CA: Sage.

Cohen, W., and D. Levinthal (1990)."Absorptive capacity: A new perspective on learning and innovation," Administrative Science Quarterly 35(1), 128-152.

Czarnitzki, D., and J. Delanote (2015). "R\&D policies for young SMEs: input and output effects," Small Business Economics 45(3), 465-485.

Dahlander, L., and D.M. Gann (2010)."How open is innovation?," Research Policy 39(6), 699-709.

Doloreux, D. (2004). "Regional Networks of Small and Medium Sized Enterprises: Evidence from the Metropolitan Area of Ottawa in Canada," European Planning Studies 12 (2), 173-189.

Dyer, J.H., and H. Singh (1998)."The relational view: Cooperative strategy and sources of interorganizational competitive advantage," Academy of Management Review 23(4), 660-679.

Ebersberger, B., C. Bloch, S.J. Herstad, and E. van de Velde (2012). "Open Innovation Practices and Their Effect on Innovation Performance," International Journal of Innovation \& Technology Management 9(6),1-22.

Edler, J., L. Georghiou, K. Blind, and E. Uyarra (2012). "Evaluating the demand side: New challenges for evaluation," Research Evaluation 21(1), 33-47.

European Commission (2005). SME definition. Available at: http://ec.europa.eu/enterprise/policies/sme/facts-figures-analysis/sme definition/index_en.htm (2011). European Innovation Scoreboard 2011. Brussels: European Commission.

European Commission (2008). The New SME Definition: User Guide and Model Declaration. Enterprise and Industry Publications: European Union Publications Office.

Faems, D., M. De Visser, P. Andries, and B. Van Looy (2010). "Technology alliance portfolio and financial performance: Value-enhancing and cost-increasing effects of open innovation," Journal of Product Innovation Management 27(6), 785-796.

Forero-Pineda, C., S.C. Waldron, and N. F. Ramirez (2010). "Business Networks and Innovation in SMEs of a Developing Country," Universidad de los Andes, Management Galleys Working Paper.

Fu, V. (1998). "sg88: Estimating generalized ordered logit models," Stata Technical Bulletin 44: 27-30. In: Stata Technical Bulletin Reprints 8, 160-164. College Station, TX: Stata Press.

Gallouj, F., and M. Savona (2009). "Innovation in services: a review of the debate and a research agenda," Journal of Evolutionary Economics 19 (2), 149-172.

Gans, J.S., and S. Stern (2003). "The product market and the market for 'ideas': commercialization strategies for technology entrepreneurs," Research Policy 32(2), 333-350.

Gassmann, O., and E. Enkel (2004). "Towards a Theory of Open Innovation: Three Core Process Archetypes," paper presented at the R\&D Management Conference, Lisbon, Portugal, July. 
Gassmann, O., E. Enkel, and H. Chesbrough (2010). "The future of open innovation," $R \& D$ Management 40(3), 213-221.

Gesing, J., D. Antons, E. Piening, M. Rese, and T.O. Salge (2015). "Joining Forces or Going for it Alone? On the Interplay among External Collaboration Partner Types, Interfirm Governance Modes, and Internal R\&D," Journal of Product Innovation Management 32(3), 424-440.

Greene, W.H. (2005). Econometric Analysis. Upper Saddle River, NJ: Pearson Prentice Hall.

Greenhalgh, C., and M. Longland (2005). "Running to Stand Still? - The Value of R\&D, Patents and Trade Marks in Innovating Manufacturing Firms," International Journal of the Economics of Business 12 (3), 307-328.

Grimpe, C., and W. Sofka (2009)."Search patterns and absorptive capacity: Low- and hightechnology sectors in European countries," Research Policy 38(3), 495-506.

Hagedoorn, J. (2002)."Inter-firm R\&D partnerships: an overview of major trends and patterns since 1960," Research Policy 31 (4), 477-492.

Helfat, C., S. Finkelstein, W. Mitchell, M. Peteraf, H. Singh, D. Teece, and S. Winter (2007). Dynamic Capabilities: Understanding Strategic Change in Organizations. Malden, MA: Blackwell.

Hipp, C., and H. Grupp (2005). "Innovation in the service sector: The demand for service-specific innovation measurement concepts and typologies," Research Policy 34(4), 517-535.

Hirsch-Kreinsen, H. (2015). "Patterns of knowledge use in 'low-tech' industries," Prometheus DOI: 10.1080/08109028.2015.1062237.

Hsu, D.H., and K. Lim (2013). "Knowledge Brokering and Organizational Innovation: Founder Imprinting Effects," Organization Science 25(4), 1134-1153.

Huang, F., and J. Rice (2009)."The role of absorptive capacity in facilitating "open innovation" outcomes: a study of Australian SMEs in the manufacturing sector," International Journal of Innovation Management 13(2), 201-220.

Huizingh, E.K.R.E. (2011). "Open innovation: State of the art and future perspectives," Technovation 31(1), 2-9.

Katila, R., and G. Ahuja (2002). "Something old, something new: A longitudinal study of search behavior and new product introduction," Academy of Management Journal 45(6), 1183-1194.

Katz, R., and T.J. Allen (1982)."Investigating the not invented here syndrome: a look at the performance, tenure and communication patterns of $50 \mathrm{R} \& \mathrm{D}$ project groups," $R \& D$ Management 12 (1), 7-19.

Kim, H., and Y. Park (2010). "The Effects of Open Innovation Activity on Performance of SMEs: The Case of Korea," International Journal of Technology Management 52(3-4), 236-256.

Kitching, J., and R. Blackburn (1998)."Intellectual property management in the small and medium enterprise (SME)," Journal of Small Business and Enterprise Development 5(4), 327-335.

Klerkx, L., and C. Leeuwis (2009)."Establishment and embedding of innovation brokers at different innovation system levels: Insights from the Dutch agricultural sector," Technological Forecasting and Social Change 76, 849-860.

Laursen, K., and A.J. Salter (2004). "Searching high and low: what types of firms use universities as a source of innovation?," Research Policy 33(8), 1201-1215.

Laursen, K., and A.J. Salter (2006). "Open for innovation: The role of openness in explaining innovation performance among U.K. manufacturing firms," Strategic Management Journal 27(2), 131-150.

Lee, S., G. Park, B. Yoon, and J. Park (2010). "Open innovation in SMEs- an intermediated network model," Research Policy 39(2), 290-300.

Leiponen, A., and J. Byma (2009). "If you cannot block, you better run: Small firms, cooperative innovation, and appropriation strategies," Research Policy 38(9), 1478-1488. 
Leiponen, A., and C.E. Helfat (2010)."Innovation objectives, knowledge sources, and the benefits of breadth," Strategic Management Journal 31(2), 224-236.

Levitt, B., and J.G. March (1988). "Organizational learning," Annual Review of Sociology 14, 319340.

Long, J.S., and J. Freese (2001). Regression Models for Categorical Dependent Variables. First edition, College Station, TX: Stata Press.

Long, J.S., and J. Freese (2006). Regression Models for Categorical Dependent Variables. Second edition, College Station, TX: Stata Press.

Love, J.H., Roper S., and P. Vahter (2014). "Learning from openness: The dynamics of breadth in external innovation linkages," Strategic Management Journal 35(11), 1703-1716.

Mazzola, E., M. Bruccoleri, and G. Perrone (2012)."The effect of inbound, outbound and coupled innovation on performance," International Journal of Innovation Management 16(6), 1-27.

Mazzola, E., G. Perrone, and D. S. Kamuriwo (2015). Network embeddedness and new product development in the biopharmaceutical industry: The moderating role of open innovation flow," International Journal of Production Economics 160, 106-119.

McPherson, M. K. and N. S. Vonortas (2012). Networks and strategic options for innovative performance in KBEs, Deliverable 1.7.3 for project AEGIS- Advancing Knowledge-Intensive Entrepreneurship and Innovation for Economic Growth and Social Well-being in Europe, EU FP7.

Mention, A.-L. (2011)."Co-operation and co-opetition as open innovation practices in the service sector: Which influence on innovation novelty?," Technovation 31(1), 44-53.

Mina, A., E. Bascavusoglu-Moreau, and A. Hughes (2014). "Open service innovation and the firm's search for external knowledge," Research Policy 43(5), 853-866.

Muscio, A. (2007). "The impact of absorptive capacity on SMEs' collaboration," Economics of Innovation and New Technology 16(8), 653-668.

Narula, R. (2004)."R\&D collaboration by SMEs: new opportunities an limitations in the face of globalization," Technovation 24 (2), 153-161.

Narula, R. and J. Hagedoorn (1999). "Innovating thorough strategic alliances: moving towards international partnerships and contractual agreements," Technovation 19 (5), 283-294.

Negassi, S. (2004). "R\&D cooperation and innovation: a microeconometric study on French firms," Research Policy 33(3), 365-384.

Ocasio, W. (1997). "Towards an attention-based view of the firm," Strategic Management Journal 18(S1), 187-206.

Opper, S., and V. Nee. (2015). "Network effects, cooperation and entrepreneurial innovation in China," Asian Business \& Management advance online publication, DOI: 10.1057/abm.2015.11

Organisation for Economic Co-operation and Development (OECD) (2006). Science, Technology and Industry Outlook, Paris: OECD Publishing.

Pakes, A., and Z. Griliches (1980). "Patents and R\&D at the firm level: A first report," Economics Letters 5(4), 377-381.

Parida, V., M. Westerberg, and J. Frishammar (2012). "Inbound open innovation activities in high tech SMEs: The impact on innovation performance," Journal of Small Business Management 50(2), 283-309.

Pinto, H., M.T. de Noronha, and C. Faustino (2015). "Knowledge and cooperation determinants of innovation networks: a mixed-methods approach to the case of Portugal," Journal of Technology Management \& Innovation 10(1), 83-102. 
Powell, W. W., and S. Grodal (2005)."Networks of Innovators", In: Oxford Handbook of Innovation, Ed. J.Fagerberg, D. C. Mowery and R.R. Nelson. Oxford: Oxford University Press. Chapter 3.

Radicic, D., G. Pugh, H. Hollanders, R. Wintjes, and J. Fairburn (2015). "The impact of innovation support programs on small and medium enterprises innovation in traditional manufacturing industries: An evaluation for seven European Union regions," Environment and Planning C: Government and Policy, doi: 10.1177/0263774X15621759.

Roper, S., J.H. Love, and J. Du (2007)."The Limits of Open Innovation: Openness and (quasi-) markets in the organization of innovation, "Aston Business School Working PaperNo.0731.

Rothwell, R., and W. Zegveld (1982). Innovation and the small and medium sized firms, London: Frances Pinter.

Santamaría, L.S., M.J. Nieto, and A. Barge-Gil (2009)."Beyond Formal R\&D: Taking Advantage of Other Sources of Innovation In Low- and Medium-Technology Industries," Research Policy 38(3), 507-517.

Savin, I. and A. Egbetokun (2013). "Emergence of innovation networks from R\&D cooperation with endogenous absorptive capacity", CEB Working Paper 13/022.

Schroll, A., and A. Mild (2011). "Open innovation modes and the role of internal R\&D. An empirical study on open innovation adoption in Europe," European Journal of Innovation Management 14(4), 475-495.

Spithoven, A., B. Clarysse, and M. Knockaert (2010). "Building absorptive capacity to organise inbound open innovation in traditional industries", Technovation 30(2), 130-141.

Spithoven, A., W. Vanhaverbeke, and N. Roijakkers (2013). "Open innovation practices in SMEs and large enterprises," Small Business Economics 41(3), 537-562.

Teece, D. J. (2007). "Explicating dynamic capabilities: the nature and microfoundations of (sustainable) enterprise performance," Strategic Management Journal 28(13), 1319-1350.

Teece, D.J., G. Pisano, and A. Shuen (1997). "Dynamic Capabilities and Strategic Management," Strategic Management Journal18(7), 509-533.

Teirlinck, P. and A. Spithoven (2013). "Research collaboration and R\&D outsourcing: Different R\&D personnel requirements in SMEs," Technovation 33 (4-5), 142-153.

UCLA (2015a). Stata Data Analysis Examples - Ordered Logistic Regression. Available at: http://www.ats.ucla.edu/stat/stata/dae/ologit.htm

UCLA (2015b). Stata Annotated Output - Ordered Logistic Regression. Available at: http://www.ats.ucla.edu/stat/stata/output/stata_ologit_output.htm

Van de Vrande, V., J.P.J. de Jong, W. Vanhaverbeke, and M. de Rochemont (2009). "Open innovation in SMEs: Trends, motives and management challenges," Technovation 29(6-7), $423-437$.

Van de Vrande, V., W. Vanhaverbeke, and O. Gassmann (2010)."Broadening the scope of open innovation: past research, current state and future directions," International Journal of Technology Management 52(3/4), 221-235.

Vanhaverbeke, W., and M. Cloodt (2014)."Theories of the firm and Open Innovation," In: New Frontiers in Open Innovation. Ed. H. Chesbrough, W. Vanhaverbeke, and J. West. Oxford: Oxford University Press, 256-280.

Van Lente, H.,M. Hekkert, R. Smits, and B. Van Waveren (2003)."Roles of systemic intermediaries in transition processes," International Journal of Innovation Management 7 (3), 1-33.

Vargo, S.L., P.P. Maglio, and M.A. Akaka (2008)."On value and value co-creation: a service systems and service logic perspective," European Management Journal 26(3), 145-152. 
Vega -Jurado, J., A. Gutiérrez-Gracia, and I. Fernández-de-Lucio (2009). "Does external knowledge sourcing matter for innovation? Evidence from the Spanish manufacturing industry," Industrial and Corporate Change 18(4), 637-670.

Verbano, C., M. Crema, and K. Venturini (forthcoming). "The Identification and Characterization of Open Innovation Profiles in Italian Small and Medium-sized Enterprises," Journal of Small Business Management DOI: 10.1111/jsbm.12091.

Verona, G., E. Prandelli, and M. Sawhney (2006). "Innovation and Virtual Environments: Towards Virtual Knowledge Brokers," Organization Studies 27(6), 765-788.

Von Hippel, E.(1988).The sources of innovation. New York: Oxford University Press.

Vossen, R.W. (1998). "Relative strengths and weaknesses of small firms in innovation," International Small Business Journal 16(3), 88-94.

Williams, R. (2006a). "Generalized ordered logit/partial proportional odds models for ordinal dependent variables," Stata Journal 6(1), 58-82.

Williams, R. (2006b)."Interpreting and using heterogeneous choice \& generalized ordered logit models," available at https://www3.nd.edu/ rwilliam/gologit2/RWNASUG2006.pdf

Wooldridge, J.M. (2010). Econometric Analysis of Cross Section and Panel Data. Second edition, MIT Press.

Wolfe, R., and W.W. Gould (1998). "sg76: An approximate likelihood-ratio test for ordinal response models," Stata Technical Bulletin 42, 24-27.Reprinted in Stata Technical Bulletin Reprints 7, 199-204. College Station, TX: Stata Press.

Wynarczyk, P., P. Piperopoulos, and M. McAdam (2013). "Open innovation in small and medium-sized firms: An overview," International Small Business Journal 31(3), 240-255.

Zahra, S. A., and G. George (2002)."Absorptive capacity: a review, reconceptualization, and extension," Academy of Management Review 27(2), 185-203.

Zeng, S. X., X. M. Xie, and C. M. Tam (2010). "Relationship between cooperation networks and innovation performance of SMEs," Technovation 30 (3), 181-194. 
Table 1. Estimation results from the generalized partial proportional odds model for the full sample and for micro firms. Dependent variable: Innovative sales-share of sales from new product and processes.

\begin{tabular}{|c|c|c|c|c|c|c|}
\hline & \multicolumn{3}{|c|}{ All firms } & \multicolumn{3}{|c|}{ Micro firms } \\
\hline & $\begin{array}{c}\text { Innovative } \\
\text { sales } \\
>10 \%\end{array}$ & $\begin{array}{r}\text { Innovative } \\
\text { sales }>\mathbf{3 0} \%\end{array}$ & $\begin{array}{r}\text { Innovative } \\
\text { sales }>\mathbf{5 0 \%}\end{array}$ & $\begin{array}{l}\text { Innovative } \\
\text { sales }>10 \%\end{array}$ & $\begin{array}{r}\text { Innovative } \\
\text { sales }>\mathbf{3 0} \%\end{array}$ & $\begin{array}{c}\text { Innovative sales } \\
>\mathbf{5 0 \%}\end{array}$ \\
\hline \multicolumn{7}{|l|}{ Variables of interest } \\
\hline \multirow[t]{2}{*}{ IP protection } & $0.864 * *$ & $0.864 * *$ & $0.864 * *$ & -1.706 & -0.185 & $1.839 * * *$ \\
\hline & $(0.356)$ & $(0.356)$ & $(0.356)$ & $(1.141)$ & $(1.117)$ & $(0.683)$ \\
\hline \multirow[t]{2}{*}{ Source_brokers } & -0.011 & -0.011 & -0.011 & 0.050 & $-0.668 * * *$ & -0.248 \\
\hline & $(0.082)$ & $(0.082)$ & $(0.082)$ & $(0.217)$ & $(0.238)$ & $(0.176)$ \\
\hline \multirow[t]{2}{*}{ Source_other_firms } & -0.055 & -0.055 & -0.055 & -0.038 & $0.936 * * *$ & 0.060 \\
\hline & $(0.109)$ & $(0.109)$ & $(0.109)$ & $(0.300)$ & $(0.331)$ & $(0.247)$ \\
\hline \multirow[t]{2}{*}{ Source_research } & -0.039 & -0.039 & -0.039 & -0.130 & -0.130 & -0.130 \\
\hline & $(0.092)$ & $(0.092)$ & $(0.092)$ & $(0.203)$ & $(0.203)$ & $(0.203)$ \\
\hline \multirow[t]{2}{*}{ Source_strategic } & -0.013 & -0.013 & -0.013 & 0.410 & $0.557 * *$ & -0.102 \\
\hline & $(0.104)$ & $(0.104)$ & $(0.104)$ & $(0.257)$ & $(0.263)$ & $(0.197)$ \\
\hline \multirow[t]{2}{*}{ Source_non_equity } & 0.038 & 0.038 & 0.038 & 0.288 & -0.448 & 0.181 \\
\hline & $(0.110)$ & $(0.110)$ & $(0.110)$ & $(0.279)$ & $(0.301)$ & $(0.242)$ \\
\hline \multirow[t]{2}{*}{ Source_networks } & $-0.175^{* *}$ & $-0.175 * *$ & $-0.175 * *$ & $-0.485^{*}$ & $-0.575 * *$ & 0.166 \\
\hline & $(0.088)$ & $(0.088)$ & $(0.088)$ & $(0.272)$ & $(0.246)$ & $(0.196)$ \\
\hline \multirow[t]{2}{*}{ Source_customers } & $0.551 * * *$ & $0.305 * * *$ & $0.219 * *$ & $1.175^{* * *}$ & 0.274 & -0.163 \\
\hline & $(0.103)$ & $(0.098)$ & $(0.102)$ & $(0.242)$ & $(0.195)$ & $(0.194)$ \\
\hline \multicolumn{7}{|l|}{ Control variables } \\
\hline \multirow[t]{2}{*}{ Export } & 0.142 & -0.106 & 0.204 & $-1.293 * * *$ & $-0.789 *$ & 0.138 \\
\hline & $(0.203)$ & $(0.198)$ & $(0.211)$ & $(0.434)$ & $(0.444)$ & $(0.358)$ \\
\hline \multirow[t]{2}{*}{ Age } & 0.027 & $-0.260 *$ & $-0.635 * * *$ & $0.721 * *$ & 0.275 & $-0.758 * * *$ \\
\hline & $(0.155)$ & $(0.156)$ & $(0.165)$ & $(0.354)$ & $(0.272)$ & $(0.291)$ \\
\hline \multirow[t]{2}{*}{ Competition } & 0.084 & -0.042 & $-0.171 *$ & $0.428 * *$ & -0.163 & $-0.482 * * *$ \\
\hline & $(0.099)$ & $(0.090)$ & $(0.093)$ & $(0.211)$ & $(0.211)$ & $(0.169)$ \\
\hline \multirow[t]{2}{*}{ R\&D personnel } & $0.494 * * *$ & $0.494 * * *$ & $0.494 * * *$ & $1.149 * * *$ & -0.053 & $0.548 * * *$ \\
\hline & $(0.091)$ & $(0.091)$ & $(0.091)$ & $(0.232)$ & $(0.179)$ & $(0.167)$ \\
\hline \multirow[t]{2}{*}{ R\&D department } & $0.342 *$ & $0.342^{*}$ & $0.342 *$ & 0.483 & 0.483 & 0.483 \\
\hline & $(0.201)$ & $(0.201)$ & $(0.201)$ & $(0.388)$ & $(0.388)$ & $(0.388)$ \\
\hline \multirow[t]{2}{*}{ Innovation capacity } & 0.224 & 0.224 & 0.224 & -0.592 & $1.569 * * *$ & -0.114 \\
\hline & $(0.208)$ & $(0.208)$ & $(0.208)$ & $(0.621)$ & $(0.494)$ & $(0.417)$ \\
\hline \multirow[t]{2}{*}{ Resources } & -0.035 & -0.035 & -0.035 & 0.072 & 0.072 & 0.072 \\
\hline & $(0.163)$ & $(0.163)$ & $(0.163)$ & $(0.291)$ & $(0.291)$ & $(0.291)$ \\
\hline \multirow[t]{2}{*}{ Technology park } & 0.251 & 0.251 & 0.251 & -0.680 & $2.846^{* * * *}$ & 0.418 \\
\hline & $(0.225)$ & $(0.225)$ & $(0.225)$ & $(0.797)$ & $(0.587)$ & $(0.391)$ \\
\hline \multirow[t]{2}{*}{ Technology platform } & $0.333^{*}$ & $0.333^{*}$ & $0.333^{*}$ & 0.140 & 0.140 & 0.140 \\
\hline & $(0.197)$ & $(0.197)$ & $(0.197)$ & $(0.323)$ & $(0.323)$ & $(0.323)$ \\
\hline \multirow[t]{2}{*}{ Small firms } & -0.268 & -0.268 & -0.268 & & & \\
\hline & $(0.204)$ & $(0.204)$ & $(0.204)$ & & & \\
\hline Medium firms & -0.006 & -0.006 & -0.006 & & & \\
\hline & $(0.262)$ & $(0.262)$ & $(0.262)$ & & & \\
\hline ICT & 0.184 & 0.184 & 0.184 & $1.770 * * *$ & $1.978 * * *$ & -0.158 \\
\hline & $(0.257)$ & $(0.257)$ & $(0.257)$ & $(0.546)$ & $(0.550)$ & $(0.568)$ \\
\hline High-tech industries & -0.044 & -0.044 & -0.044 & $1.338^{*}$ & $-1.132 *$ & 0.002 \\
\hline & $(0.298)$ & $(0.298)$ & $(0.298)$ & $(0.696)$ & $(0.596)$ & $(0.550)$ \\
\hline Medium high- tech & $0.488^{*}$ & $0.488^{*}$ & $0.488 *$ & $2.050 * * *$ & $2.616 * * *$ & 0.548 \\
\hline & $(0.293)$ & $(0.293)$ & $(0.293)$ & $(0.674)$ & $(0.712)$ & $(0.558)$ \\
\hline
\end{tabular}




\begin{tabular}{lccc|ccc} 
Medium low-tech & -0.144 & -0.144 & -0.144 & $1.823 * *$ & -0.038 & $-1.189 *$ \\
& $(0.292)$ & $(0.292)$ & $(0.292)$ & $(0.859)$ & $(0.592)$ & $(0.670)$ \\
Low-tech industries & $0.483^{*}$ & $0.483 *$ & $0.483 *$ & $2.368 * * *$ & -0.291 & -0.412 \\
& $(0.283)$ & $(0.283)$ & $(0.283)$ & $(0.668)$ & $(0.672)$ & $(0.710)$ \\
Innovation leaders & 0.009 & 0.009 & 0.009 & 0.692 & -1.039 & 0.434 \\
& $(0.251)$ & $(0.251)$ & $(0.251)$ & $(0.694)$ & $(0.633)$ & $(0.431)$ \\
Moderate innovators & 0.212 & 0.212 & 0.212 & 0.208 & 0.208 & 0.208 \\
& $(0.197)$ & $(0.197)$ & $(0.197)$ & $(0.347)$ & $(0.347)$ & $(0.347)$ \\
Modest innovators & $0.704 * * *$ & $0.704 * * *$ & $0.704 * * *$ & $3.102 * * *$ & $2.189 * * *$ & 0.763 \\
& $(0.266)$ & $(0.266)$ & $(0.266)$ & $(0.877)$ & $(0.654)$ & $(0.633)$ \\
Constant & $-1.817 * * *$ & $-1.052^{*}$ & -0.320 & $-7.907 * * *$ & -1.935 & 1.885 \\
& $(0.633)$ & $(0.589)$ & $(0.613)$ & $(1.780)$ & $(1.336)$ & $(1.199)$ \\
No of observations & 620 & & & 304 & & $185.89 * * *$ \\
Wald $\chi^{2}$ test & $194.33 * * *$ & & & -247.137 & & \\
Log likelihood & -705.660 & & & 0.350 & & \\
McFadden's pseudo $\mathrm{R}^{2}$ & 0.134 & & & & \\
\hline Notes: Robust standard & & & &
\end{tabular}

Notes: Robust standard errors in parentheses. In the full sample, the reference firm size is micro firms. For both all firms and micro firms, the reference country group is 'Innovation followers'; the reference industry is the service sector. $* * * p<0.01, * * p<0.05, * p<0.1$. 
Table 2. Estimation results from the ordered logit model for small and medium firms and for firms in ICT and service sectors. Dependent variable: Innovative sales-share of sales from new product and processes.

\begin{tabular}{|c|c|c|c|c|}
\hline & Small firms & Medium firms & ICT & Services \\
\hline \multicolumn{5}{|l|}{ Variables of interest } \\
\hline \multirow[t]{2}{*}{ IP protection } & $1.426 * *$ & 0.362 & 0.232 & $4.070 * * *$ \\
\hline & $(0.576)$ & $(0.826)$ & (1.256) & $(1.319)$ \\
\hline \multirow[t]{2}{*}{ Source_brokers } & -0.107 & 0.183 & -0.141 & -0.299 \\
\hline & $(0.147)$ & $(0.286)$ & $(0.223)$ & $(0.262)$ \\
\hline \multirow[t]{2}{*}{ Source_other_firms } & 0.048 & $-0.734 * *$ & $0.807 * *$ & -0.479 \\
\hline & $(0.192)$ & $(0.319)$ & $(0.337)$ & $(0.357)$ \\
\hline \multirow[t]{2}{*}{ Source_research } & 0.007 & -0.000 & -0.334 & -0.028 \\
\hline & $(0.184)$ & $(0.266)$ & $(0.266)$ & $(0.247)$ \\
\hline \multirow[t]{2}{*}{ Source_strategic } & -0.010 & -0.278 & -0.191 & 0.028 \\
\hline & $(0.212)$ & $(0.369)$ & $(0.274)$ & $(0.334)$ \\
\hline \multirow[t]{2}{*}{ Source_non_equity } & 0.045 & 0.164 & 0.035 & 0.418 \\
\hline & $(0.212)$ & $(0.329)$ & $(0.278)$ & $(0.374)$ \\
\hline \multirow[t]{2}{*}{ Source_networks } & $-0.261^{*}$ & -0.199 & -0.176 & 0.131 \\
\hline & $(0.152)$ & $(0.249)$ & $(0.197)$ & $(0.301)$ \\
\hline \multirow[t]{2}{*}{ Source_customers } & $0.264 *$ & $0.605^{* *}$ & 0.279 & 0.266 \\
\hline & $(0.157)$ & $(0.288)$ & $(0.205)$ & $(0.303)$ \\
\hline \multicolumn{5}{|l|}{ Control variables } \\
\hline \multirow[t]{2}{*}{ Export } & 0.445 & 0.397 & -0.505 & 0.249 \\
\hline & $(0.352)$ & $(0.608)$ & $(0.420)$ & $(0.515)$ \\
\hline \multirow[t]{2}{*}{ Age } & $-0.717 * *$ & 0.183 & -0.498 & -0.081 \\
\hline & $(0.299)$ & $(0.466)$ & $(0.387)$ & $(0.379)$ \\
\hline \multirow[t]{2}{*}{ Competition } & -0.058 & 0.238 & 0.069 & 0.009 \\
\hline & $(0.147)$ & $(0.236)$ & $(0.206)$ & $(0.279)$ \\
\hline \multirow[t]{2}{*}{ R\&D personnel } & 0.135 & $0.834 * *$ & $0.910 * * *$ & 0.444 \\
\hline & $(0.186)$ & $(0.363)$ & $(0.240)$ & $(0.291)$ \\
\hline \multirow[t]{2}{*}{$\mathrm{R} \& \mathrm{D}$ department } & $0.532 *$ & 0.578 & 0.507 & 0.003 \\
\hline & $(0.306)$ & $(0.555)$ & $(0.480)$ & $(0.751)$ \\
\hline \multirow[t]{2}{*}{ Innovation capacity } & 0.288 & -0.055 & -0.495 & $1.122 * *$ \\
\hline & $(0.388)$ & $(0.706)$ & $(0.539)$ & $(0.536)$ \\
\hline \multirow[t]{2}{*}{ Resources } & -0.226 & $1.163^{* *}$ & 0.236 & $1.168^{* *}$ \\
\hline & $(0.316)$ & $(0.486)$ & $(0.443)$ & $(0.488)$ \\
\hline \multirow[t]{2}{*}{ Technology park } & -0.076 & -0.346 & -0.110 & 0.975 \\
\hline & $(0.429)$ & $(0.815)$ & $(0.526)$ & $(0.782)$ \\
\hline \multirow[t]{2}{*}{ Technology platform } & 0.307 & 0.756 & 0.503 & -0.193 \\
\hline & $(0.380)$ & $(0.463)$ & $(0.477)$ & $(0.544)$ \\
\hline \multirow[t]{2}{*}{ Small firms } & - & - & -0.322 & 0.816 \\
\hline & & & $(0.558)$ & $(0.612)$ \\
\hline \multirow[t]{2}{*}{ Medium firms } & - & - & -0.414 & -0.436 \\
\hline & & & $(0.557)$ & $(0.786)$ \\
\hline \multirow[t]{2}{*}{ ICT } & -0.616 & 0.161 & - & - \\
\hline & $(0.542)$ & $(0.818)$ & & \\
\hline \multirow[t]{2}{*}{ High-tech industries } & -0.674 & -0.813 & - & - \\
\hline & $(0.533)$ & (1.035) & & \\
\hline Medium high-tech & -0.289 & 0.419 & - & - \\
\hline & $(0.564)$ & $(0.867)$ & & \\
\hline
\end{tabular}




\begin{tabular}{lcccc} 
Medium low-tech & $-1.209 * *$ & 0.260 & - & - \\
Low-techindustries & $(0.615)$ & $(0.849)$ & & - \\
& -0.372 & 1.165 & - & \\
Innovation leaders & $(0.464)$ & $(0.912)$ & & $1.411^{*}$ \\
& -0.141 & -0.689 & 0.481 & $(0.821)$ \\
Moderate innovators & $(0.429)$ & $(0.814)$ & $(0.685)$ & $0.998^{*}$ \\
& 0.119 & 0.004 & 0.124 & $(0.560)$ \\
Modest innovators & $(0.378)$ & $(0.584)$ & $(0.480)$ & $2.511 * * *$ \\
& 0.430 & 0.647 & 0.490 & $(0.759)$ \\
Cut1 & $(0.537)$ & $(0.642)$ & $(0.591)$ & 2.518 \\
& $-2.189 *$ & $2.894^{*}$ & 0.561 & $(1.600)$ \\
Cut2 & $(1.176)$ & $(1.666)$ & $(1.609)$ & $3.716^{* *}$ \\
& -1.058 & $4.821^{* * *}$ & 1.927 & $(1.595)$ \\
Cut3 & $(1.189)$ & $(1.725)$ & $(1.629)$ & $4.249 * * *$ \\
& -0.367 & $5.772^{* * *}$ & 2.649 & $(1.579)$ \\
Number of observations & $(1.188)$ & $(1.741)$ & $(1.639)$ & 118 \\
Wald $\chi^{2}$ test & 200 & 116 & 127 & $58.63 * * *$ \\
Log likelihood & $50.89 * * *$ & $58.36 * *$ & $50.49 * * *$ & -118.258 \\
McFadden's pseudo $\mathrm{R}^{2}$ & -240.732 & -127.985 & -139.340 & 0.163 \\
\hline Nos: Robs & 0.096 & 0.188 & 0.163 & 0.204
\end{tabular}

Notes: Robust standard errors in parentheses. The reference country group is 'Innovation followers'. In the subsamples of small and medium firms, the reference industry is the service sector. In the subsamples of firms operating in the ICT and service sectors, the reference firm size is micro firms. $* * * p<0.01, * * p<0.05, * p<0.1$. 
Table 3. Estimation results from generalized partial proportional odds model for high tech and medium high-tech SMEs and for low tech and medium low-tech SMEs. Dependent variable: Innovative sales-share of sales from new product and processes.

\begin{tabular}{|c|c|c|c|c|c|c|}
\hline & \multicolumn{3}{|c|}{ High tech and medium high-tech } & \multicolumn{3}{|c|}{ Low tech and medium low-tech } \\
\hline & $\begin{array}{l}\text { Innovative } \\
\text { sales }>10 \%\end{array}$ & $\begin{array}{l}\text { Innovative } \\
\text { sales }>30 \%\end{array}$ & $\begin{array}{l}\text { Innovative } \\
\text { sales }>50 \%\end{array}$ & $\begin{array}{l}\text { Innovative } \\
\text { sales }>10 \%\end{array}$ & $\begin{array}{l}\text { Innovative } \\
\text { sales }>\mathbf{3 0 \%}\end{array}$ & $\begin{array}{l}\text { Innovative } \\
\text { sales }>50 \%\end{array}$ \\
\hline \multicolumn{7}{|l|}{$\begin{array}{l}\text { Variables of } \\
\text { interest }\end{array}$} \\
\hline IP protection & $\begin{array}{c}0.222 \\
(0.511)\end{array}$ & $\begin{array}{c}0.222 \\
(0.511)\end{array}$ & $\begin{array}{c}0.222 \\
(0.511)\end{array}$ & $\begin{array}{l}2.304 * * \\
(0.895)\end{array}$ & $\begin{array}{c}2.304 * * \\
(0.895)\end{array}$ & $\begin{array}{c}2.304 * * \\
(0.895)\end{array}$ \\
\hline Source_brokers & $\begin{array}{c}0.123 \\
(0.209)\end{array}$ & $\begin{array}{c}0.123 \\
(0.209)\end{array}$ & $\begin{array}{c}0.123 \\
(0.209)\end{array}$ & $\begin{array}{c}-0.447 * * \\
(0.221)\end{array}$ & $\begin{array}{c}-0.447 * * \\
(0.221)\end{array}$ & $\begin{array}{c}-0.447 * * \\
(0.221)\end{array}$ \\
\hline Source_other_firms & $\begin{array}{l}-0.401 * \\
(0.234)\end{array}$ & $\begin{array}{l}-0.401^{*} \\
(0.234)\end{array}$ & $\begin{array}{l}-0.401 * \\
(0.234)\end{array}$ & $\begin{array}{l}-0.157 \\
(0.196)\end{array}$ & $\begin{array}{l}-0.157 \\
(0.196)\end{array}$ & $\begin{array}{l}-0.157 \\
(0.196)\end{array}$ \\
\hline Source_research & $\begin{array}{l}-0.143 \\
(0.271)\end{array}$ & $\begin{array}{c}0.923 * * * \\
(0.302)\end{array}$ & $\begin{array}{l}-0.349 \\
(0.396)\end{array}$ & $\begin{array}{c}0.478^{* *} \\
(0.215)\end{array}$ & $\begin{array}{c}0.478^{* *} \\
(0.215)\end{array}$ & $\begin{array}{c}0.478^{* *} \\
(0.215)\end{array}$ \\
\hline Source_strategic & $\begin{array}{l}-0.168 \\
(0.323)\end{array}$ & $\begin{array}{c}1.478 * * * \\
(0.304)\end{array}$ & $\begin{array}{l}-0.295 \\
(0.276)\end{array}$ & $\begin{array}{l}-0.187 \\
(0.226)\end{array}$ & $\begin{array}{l}-0.187 \\
(0.226)\end{array}$ & $\begin{array}{l}-0.187 \\
(0.226)\end{array}$ \\
\hline Source_non_equity & $\begin{array}{c}0.231 \\
(0.255)\end{array}$ & $\begin{array}{l}-0.261 \\
(0.264)\end{array}$ & $\begin{array}{c}0.204 \\
(0.293)\end{array}$ & $\begin{array}{l}-0.337 \\
(0.325)\end{array}$ & $\begin{array}{c}0.762 * * \\
(0.314)\end{array}$ & $\begin{array}{c}0.114 \\
(0.422)\end{array}$ \\
\hline Source_networks & $\begin{array}{c}0.297 \\
(0.268)\end{array}$ & $\begin{array}{c}-0.769 * * * \\
(0.245)\end{array}$ & $\begin{array}{c}0.062 \\
(0.231)\end{array}$ & $\begin{array}{l}-0.400 \\
(0.292)\end{array}$ & $\begin{array}{c}-1.811 * * * \\
(0.364)\end{array}$ & $\begin{array}{l}-0.371 \\
(0.452)\end{array}$ \\
\hline Source_customers & $\begin{array}{c}0.564 * * \\
(0.281)\end{array}$ & $\begin{array}{c}-0.923 * * * \\
(0.271)\end{array}$ & $\begin{array}{c}0.306 \\
(0.362)\end{array}$ & $\begin{array}{c}1.273 * * * \\
(0.288)\end{array}$ & $\begin{array}{l}0.520^{*} \\
(0.300)\end{array}$ & $\begin{array}{l}-0.345 \\
(0.366)\end{array}$ \\
\hline Control variables & & & & & & \\
\hline Export & $\begin{array}{c}0.366 \\
(0.632)\end{array}$ & $\begin{array}{l}-0.773 \\
(0.551)\end{array}$ & $\begin{array}{c}0.473 \\
(0.593)\end{array}$ & $\begin{array}{c}1.145 * * \\
(0.526)\end{array}$ & $\begin{array}{l}-0.385 \\
(0.486)\end{array}$ & $\begin{array}{c}2.262 * * \\
(1.111)\end{array}$ \\
\hline Age & $\begin{array}{c}0.687 * * \\
(0.326)\end{array}$ & $\begin{array}{c}0.300 \\
(0.310)\end{array}$ & $\begin{array}{c}-1.775 * * * \\
(0.443)\end{array}$ & $\begin{array}{c}0.291 \\
(0.341)\end{array}$ & $\begin{array}{l}-0.568 \\
(0.354)\end{array}$ & $\begin{array}{c}-2.522 * * * \\
(0.813)\end{array}$ \\
\hline Competition & $\begin{array}{l}-0.167 \\
(0.158)\end{array}$ & $\begin{array}{l}-0.167 \\
(0.158)\end{array}$ & $\begin{array}{l}-0.167 \\
(0.158)\end{array}$ & $\begin{array}{l}-0.153 \\
(0.273)\end{array}$ & $\begin{array}{l}-0.153 \\
(0.273)\end{array}$ & $\begin{array}{l}-0.153 \\
(0.273)\end{array}$ \\
\hline R\&D personnel & $\begin{array}{c}0.035 \\
(0.245)\end{array}$ & $\begin{array}{l}-0.125 \\
(0.217)\end{array}$ & $\begin{array}{c}0.922 * * * \\
(0.243)\end{array}$ & $\begin{array}{l}-0.067 \\
(0.245)\end{array}$ & $\begin{array}{l}-0.067 \\
(0.245)\end{array}$ & $\begin{array}{l}-0.067 \\
(0.245)\end{array}$ \\
\hline R\&D department & $\begin{array}{l}0.749^{*} \\
(0.411)\end{array}$ & $\begin{array}{l}0.749^{*} \\
(0.411)\end{array}$ & $\begin{array}{l}0.749^{*} \\
(0.411)\end{array}$ & $\begin{array}{c}-1.315^{* *} \\
(0.615)\end{array}$ & $\begin{array}{c}1.388^{* * * *} \\
(0.508)\end{array}$ & $\begin{array}{l}1.593^{* *} \\
(0.638)\end{array}$ \\
\hline Innovation capacity & $\begin{array}{l}-0.822 \\
(0.693)\end{array}$ & $\begin{array}{c}1.755 * * * \\
(0.501)\end{array}$ & $\begin{array}{c}0.053 \\
(0.509)\end{array}$ & $\begin{array}{l}1.189 * * \\
(0.544)\end{array}$ & $\begin{array}{l}1.189 * * \\
(0.544)\end{array}$ & $\begin{array}{l}1.189 * * \\
(0.544)\end{array}$ \\
\hline Resources & $\begin{array}{c}0.764 \\
(0.511)\end{array}$ & $\begin{array}{l}-0.631 \\
(0.478)\end{array}$ & $\begin{array}{c}-1.100 * * \\
(0.517)\end{array}$ & $\begin{array}{l}-0.447 \\
(0.387)\end{array}$ & $\begin{array}{l}-0.447 \\
(0.387)\end{array}$ & $\begin{array}{l}-0.447 \\
(0.387)\end{array}$ \\
\hline Technology park & $\begin{array}{c}0.257 \\
(0.432)\end{array}$ & $\begin{array}{c}0.257 \\
(0.432)\end{array}$ & $\begin{array}{c}0.257 \\
(0.432)\end{array}$ & $\begin{array}{c}0.010 \\
(0.529)\end{array}$ & $\begin{array}{c}0.010 \\
(0.529)\end{array}$ & $\begin{array}{c}0.010 \\
(0.529)\end{array}$ \\
\hline Technology platform & $\begin{array}{l}-0.403 \\
(0.507)\end{array}$ & $\begin{array}{l}-0.403 \\
(0.507)\end{array}$ & $\begin{array}{l}-0.403 \\
(0.507)\end{array}$ & $\begin{array}{c}0.401 \\
(0.784)\end{array}$ & $\begin{array}{c}4.113^{* * * *} \\
(0.855)\end{array}$ & $\begin{array}{l}1.478^{*} \\
(0.848)\end{array}$ \\
\hline Small firms & $\begin{array}{c}0.747 \\
(0.483)\end{array}$ & $\begin{array}{c}0.396 \\
(0.464)\end{array}$ & $\begin{array}{c}-1.268 * * \\
(0.523)\end{array}$ & $\begin{array}{l}-0.941 \\
(0.655)\end{array}$ & $\begin{array}{c}0.783 \\
(0.654)\end{array}$ & $\begin{array}{c}0.459 \\
(0.844)\end{array}$ \\
\hline Medium firms & $\begin{array}{c}0.211 \\
(0.545)\end{array}$ & $\begin{array}{c}0.211 \\
(0.545)\end{array}$ & $\begin{array}{c}0.211 \\
(0.545)\end{array}$ & $\begin{array}{c}0.625 \\
(0.652)\end{array}$ & $\begin{array}{c}0.625 \\
(0.652)\end{array}$ & $\begin{array}{c}0.625 \\
(0.652)\end{array}$ \\
\hline Innovation leaders & $\begin{array}{c}-1.944 * * \\
(0.813)\end{array}$ & $\begin{array}{c}1.817 * * * \\
(0.624)\end{array}$ & $\begin{array}{l}-0.252 \\
(0.558)\end{array}$ & $\begin{array}{c}-2.009 * * \\
(0.854)\end{array}$ & $\begin{array}{c}-1.689 * * * \\
(0.655)\end{array}$ & $\begin{array}{c}2.673 * * \\
(1.139)\end{array}$ \\
\hline Moderate innovators & -0.921 & $1.326^{* *}$ & -0.805 & 0.012 & -0.176 & $1.999 * *$ \\
\hline
\end{tabular}




\begin{tabular}{lccc|ccc} 
& $(0.770)$ & $(0.562)$ & $(0.676)$ & $(0.538)$ & $(0.529)$ & $(0.887)$ \\
Modest innovators & -0.045 & -0.045 & -0.045 & $-1.253^{*}$ & $1.744^{*}$ & $1.938^{*}$ \\
& $(0.649)$ & $(0.649)$ & $(0.649)$ & $(0.651)$ & $(1.014)$ & $(1.046)$ \\
Constant & -1.526 & -1.495 & $4.157^{* * *}$ & -0.932 & 0.596 & 3.313 \\
& $(1.351)$ & $(1.141)$ & $(1.432)$ & $(1.452)$ & $(1.487)$ & $(2.357)$ \\
Log likelihood & -183.625 & & & -137.783 & & \\
Wald $\chi^{2}$ & $88.05^{* * *}$ & & & $137.73^{* * *}$ & & \\
Pseudo $\mathrm{R}^{2}$ & 0.313 & & & 0.380 & & \\
No of observations & 210 & & & 165 & & \\
\hline
\end{tabular}

Notes: Robust standard errors in parentheses. The reference country group is 'Innovation followers'. The reference firm size is micro firms. $* * * p<0.01, * * p<0.05, * p<0.1$. 
Table 4. Summary of results: all 8 models; all variables of interest plus selected control variables (statistically significant results at $1 \%, 5 \%$ and $10 \%$ )

\begin{tabular}{|c|c|c|c|c|c|c|c|c|c|c|c|c|c|c|c|c|}
\hline \multirow{2}{*}{\begin{tabular}{l}
\multicolumn{1}{c}{ Category of firm } \\
Variables of \\
interest
\end{tabular}} & \multicolumn{3}{|c|}{ All (T.1) } & \multicolumn{3}{|c|}{ Micro (T.1) } & \multirow{2}{*}{$\begin{array}{c}\text { Small } \\
\text { (T.2) }\end{array}$} & \multirow{2}{*}{$\begin{array}{c}\text { Medium } \\
(\text { T.2) }\end{array}$} & \multicolumn{3}{|c|}{ High-tech (T.3) } & \multicolumn{3}{|c|}{ Low-tech (T.3) } & \multirow{2}{*}{$\begin{array}{l}\text { ICT } \\
(\mathbf{T . 2}) \\
\end{array}$} & \multirow{2}{*}{$\begin{array}{c}\text { Service } \\
\text { (T.2) }\end{array}$} \\
\hline & $\begin{array}{c}\text { Inn. } \\
\text { sales } \\
>10 \%\end{array}$ & $\begin{array}{c}\text { Inn. } \\
\text { sales } \\
>30 \% \\
\end{array}$ & $\begin{array}{c}\text { Inn. } \\
\text { sales } \\
>50 \% \\
\end{array}$ & $\begin{array}{c}\text { Inn. } \\
\text { sales } \\
>10 \% \\
\end{array}$ & $\begin{array}{c}\text { Inn. } \\
\text { sales } \\
>\mathbf{3 0 \%} \\
\end{array}$ & $\begin{array}{c}\text { Inn. } \\
\text { sales } \\
>\mathbf{5 0 \%} \\
\end{array}$ & & & $\begin{array}{c}\text { Inn. } \\
\text { sales } \\
>10 \%\end{array}$ & $\begin{array}{c}\text { Inn. } \\
\text { sales } \\
>\mathbf{3 0 \%} \\
\end{array}$ & $\begin{array}{c}\text { Inn. } \\
\text { sales } \\
>\mathbf{5 0 \%} \\
\end{array}$ & $\begin{array}{c}\text { Inn. } \\
\text { sales } \\
>10 \%\end{array}$ & $\begin{array}{c}\text { Inn. } \\
\text { sales } \\
>\mathbf{3 0} \% \\
\end{array}$ & $\begin{array}{c}\text { Inn. } \\
\text { sales } \\
>\mathbf{5 0 \%} \\
\end{array}$ & & \\
\hline Source brokers & & & & & - & & & & & & & - & - & - & & \\
\hline Source_other_firms & & & & & + & & & - & - & - & - & & & & + & \\
\hline Source_research & & & & & & & & & & + & & + & + & + & & \\
\hline Source_strategic & & & & & + & & & & & + & & & & & & \\
\hline Source_non_equity & & & & & & & & & & & & & + & & & \\
\hline Source_networks & - & - & - & - & - & & - & & & - & & & - & & & \\
\hline Source_customers & + & + & + & + & & & + & + & + & - & & + & + & & & \\
\hline \multicolumn{17}{|l|}{$\begin{array}{l}\text { Selected control } \\
\text { variables }\end{array}$} \\
\hline IP protection & + & + & + & & & + & + & & & & & + & + & + & & + \\
\hline \multicolumn{17}{|l|}{$\begin{array}{l}\text { Absorptive } \\
\text { capacity }\end{array}$} \\
\hline R\&D personnel & + & + & + & + & & + & & + & & & + & & & & + & \\
\hline R\&D department & + & + & + & & & & + & & + & + & + & - & + & + & & \\
\hline \multicolumn{17}{|l|}{ Quasi fixed effects } \\
\hline Inn. Capacity & & & & & + & & & & & + & & + & + & + & & + \\
\hline Inn. Resources & & & & & & & & + & & & - & & & & & + \\
\hline Firm age & & - & - & + & & - & - & & + & & - & & & - & & \\
\hline
\end{tabular}

Notes: +/- indicate statistically significant positive/negative estimates; $\mathrm{T}=$ table; Inn. = Innovative. 


\section{Appendix}

Table A1. Variable definition and descriptive statistics (mean and standard deviation)

\begin{tabular}{|c|c|c|c|c|c|c|c|c|c|}
\hline Variables & Variable construction & $\begin{array}{c}\text { All } \\
\text { firms }\end{array}$ & $\begin{array}{l}\text { Micro } \\
\text { firms }\end{array}$ & $\begin{array}{l}\text { Small } \\
\text { firms }\end{array}$ & $\begin{array}{l}\text { Medium } \\
\text { firms }\end{array}$ & ICT & $\begin{array}{c}\text { High } \\
\text { tech }\end{array}$ & $\begin{array}{l}\text { Low } \\
\text { tech }\end{array}$ & Services \\
\hline & & $\begin{array}{c}\text { Mean } \\
\text { (SD) }\end{array}$ & $\begin{array}{c}\text { Mean } \\
\text { (SD) }\end{array}$ & $\begin{array}{c}\text { Mean } \\
\text { (SD) }\end{array}$ & $\begin{array}{c}\text { Mean } \\
\text { (SD) }\end{array}$ & $\begin{array}{c}\text { Mean } \\
\text { (SD) }\end{array}$ & $\begin{array}{c}\text { Mean } \\
\text { (SD) }\end{array}$ & $\begin{array}{c}\text { Mean } \\
\text { (SD) }\end{array}$ & $\begin{array}{c}\text { Mean } \\
\text { (SD) }\end{array}$ \\
\hline $\begin{array}{l}\text { Innovative sales - share of sales } \\
\text { from new products and processes } \\
\text { (Innovative sales) }\end{array}$ & $\begin{array}{l}\text { Categorical variable }=1 \text { if the share is } 0-10 \% \text {; } \\
=2 \text { if the share is } 11-20 \% ;=3 \text { if the share is } 21- \\
30 \% ;=4 \text { if the share is } 31-40 \% ;=5 \text { if the share } \\
\text { is } 41-50 \% ;=6 \text { if the share is }>50 \%\end{array}$ & $\begin{array}{c}2.537 \\
(1.263)\end{array}$ & $\begin{array}{c}2.671 \\
(1.309)\end{array}$ & $\begin{array}{c}2.390 \\
(1.235)\end{array}$ & $\begin{array}{c}2.440 \\
(1.159)\end{array}$ & $\begin{array}{c}2.654 \\
(1.243)\end{array}$ & $\begin{array}{c}2.748 \\
(1.263)\end{array}$ & $\begin{array}{c}2.327 \\
(1.211)\end{array}$ & $\begin{array}{c}2.331 \\
(1.295)\end{array}$ \\
\hline $\begin{array}{l}\text { Use of online technology or } \\
\text { knowledge brokers/intermediaries } \\
\text { (Source_brokers) }\end{array}$ & $\begin{array}{l}\text { Categorical variable }=3 \text { if the response was } \\
\text { 'Apply extensively'; }=2 \text { if 'Apply'; }=1 \text { if } \\
\text { 'Neutral'; =0 if 'Don't apply' or 'Don't apply at } \\
\text { all' }\end{array}$ & $\begin{array}{c}1.053 \\
(1.011)\end{array}$ & $\begin{array}{c}1.105 \\
(1.060)\end{array}$ & $\begin{array}{l}1.020 \\
(0.992)\end{array}$ & $\begin{array}{c}0.974 \\
(0.909)\end{array}$ & $\begin{array}{c}1.173 \\
(1.070)\end{array}$ & $\begin{array}{c}0.976 \\
(0.951)\end{array}$ & $\begin{array}{c}1.073 \\
(1.009)\end{array}$ & $\begin{array}{c}1.034 \\
(1.054)\end{array}$ \\
\hline $\begin{array}{l}\text { Informal networking with other } \\
\text { firms (Source_other_firms) }\end{array}$ & $\begin{array}{l}\text { Categorical variable }=3 \text { if the response was } \\
\text { 'Apply extensively'; }=2 \text { if 'Apply'; }=1 \text { if } \\
\text { 'Neutral'; }=0 \text { if 'Don't apply' or 'Don't apply at } \\
\text { all' }\end{array}$ & $\begin{array}{c}1.666 \\
(0.984)\end{array}$ & $\begin{array}{c}1.701 \\
(1.001)\end{array}$ & $\begin{array}{l}1.650 \\
(0.934)\end{array}$ & $\begin{array}{c}1.603 \\
(1.029)\end{array}$ & $\begin{array}{c}1.717 \\
(0.908)\end{array}$ & $\begin{array}{c}1.686 \\
(0.910)\end{array}$ & $\begin{array}{c}1.588 \\
(1.110)\end{array}$ & $\begin{array}{c}1.686 \\
(1.010)\end{array}$ \\
\hline $\begin{array}{l}\text { Informal networking with } \\
\text { research organizations } \\
\text { (Source_research) }\end{array}$ & $\begin{array}{l}\text { Categorical variable }=3 \text { if the response was } \\
\text { 'Apply extensively'; }=2 \text { if 'Apply'; }=1 \text { if } \\
\text { 'Neutral'; }=0 \text { if 'Don't apply' or 'Don't apply at } \\
\text { all' }\end{array}$ & $\begin{array}{c}1.473 \\
(1.068)\end{array}$ & $\begin{array}{c}1.411 \\
(1.107)\end{array}$ & $\begin{array}{l}1.550 \\
(0.981)\end{array}$ & $\begin{array}{l}1.500 \\
(1.107)\end{array}$ & $\begin{array}{c}1.520 \\
(1.060)\end{array}$ & $\begin{array}{l}1.652 \\
(0.972)\end{array}$ & $\begin{array}{c}1.333 \\
(1.133)\end{array}$ & $\begin{array}{c}1.297 \\
(1.104)\end{array}$ \\
\hline $\begin{array}{l}\text { Strategic alliances with other } \\
\text { firms (Source_strategic) }\end{array}$ & $\begin{array}{l}\text { Categorical variable }=3 \text { if the response was } \\
\text { 'Apply extensively'; }=2 \text { if 'Apply'; }=1 \text { if } \\
\text { 'Neutral'; =0 if 'Don't apply' or 'Don't apply at } \\
\text { all' }\end{array}$ & $\begin{array}{c}1.332 \\
(1.018)\end{array}$ & $\begin{array}{c}1.414 \\
(1.037)\end{array}$ & $\begin{array}{c}1.345 \\
(1.015)\end{array}$ & $\begin{array}{c}1.095 \\
(0.942)\end{array}$ & $\begin{array}{c}1.457 \\
(0.949)\end{array}$ & $\begin{array}{c}1.390 \\
(1.017)\end{array}$ & $\begin{array}{c}1.164 \\
(1.008)\end{array}$ & $\begin{array}{c}1.331 \\
(1.086)\end{array}$ \\
\hline $\begin{array}{l}\text { Non-equity alliances with other } \\
\text { firms (Source_non_equity) }\end{array}$ & $\begin{array}{l}\text { Categorical variable }=3 \text { if the response was } \\
\text { 'Apply extensively'; }=2 \text { if 'Apply'; }=1 \text { if } \\
\text { 'Neutral'; }=0 \text { if 'Don't apply' or 'Don't apply at } \\
\text { all' }\end{array}$ & $\begin{array}{c}0.932 \\
(0.916)\end{array}$ & $\begin{array}{c}1.013 \\
(0.947)\end{array}$ & $\begin{array}{c}0.850 \\
(0.912)\end{array}$ & $\begin{array}{c}0.862 \\
(0.822)\end{array}$ & $\begin{array}{c}0.992 \\
(0.895)\end{array}$ & $\begin{array}{c}0.962 \\
(0.963)\end{array}$ & $\begin{array}{c}0.897 \\
(0.888)\end{array}$ & $\begin{array}{c}0.864 \\
(0.896)\end{array}$ \\
\hline $\begin{array}{l}\text { Participation in innovation } \\
\text { networks, S\&T parks, clusters } \\
\text { etc. (Source_networks) }\end{array}$ & $\begin{array}{l}\text { Categorical variable }=3 \text { if the response was } \\
\text { 'Apply extensively'; }=2 \text { if 'Apply'; }=1 \text { if } \\
\text { 'Neutral'; }=0 \text { if 'Don't apply' or 'Don't apply at } \\
\text { all' }\end{array}$ & $\begin{array}{c}1.206 \\
(1.063)\end{array}$ & $\begin{array}{c}1.237 \\
(1.079)\end{array}$ & $\begin{array}{c}1.200 \\
(1.051)\end{array}$ & $\begin{array}{c}1.138 \\
(1.046)\end{array}$ & $\begin{array}{c}0.992 \\
(0.895)\end{array}$ & $\begin{array}{c}1.333 \\
(1.091)\end{array}$ & $\begin{array}{c}0.958 \\
(1.008)\end{array}$ & $\begin{array}{c}1.212 \\
(1.045)\end{array}$ \\
\hline $\begin{array}{l}\text { Close involvement of end } \\
\text { users/customers in idea } \\
\text { generation/concept development }\end{array}$ & $\begin{array}{l}\text { Categorical variable }=3 \text { if the response was } \\
\text { 'Apply extensively'; }=2 \text { if 'Apply'; }=1 \text { if } \\
\text { 'Neutral'; }=0 \text { if 'Don't apply' or 'Don't apply at }\end{array}$ & $\begin{array}{c}1.667 \\
(1.031)\end{array}$ & $\begin{array}{c}1.678 \\
(1.057)\end{array}$ & $\begin{array}{c}1.645 \\
(0.997)\end{array}$ & $\begin{array}{c}1.672 \\
(1.028)\end{array}$ & $\begin{array}{c}1.315 \\
(1.059)\end{array}$ & $\begin{array}{c}1.733 \\
(1.051)\end{array}$ & $\begin{array}{c}1.576 \\
(1.025)\end{array}$ & $\begin{array}{c}1.661 \\
(1.048)\end{array}$ \\
\hline
\end{tabular}




\begin{tabular}{|c|c|c|c|c|c|c|c|c|c|}
\hline (Source_customers) & all' & & & & & & & & \\
\hline $\begin{array}{l}\text { Protection mechanisms }(I P \\
\text { protection })\end{array}$ & $\begin{array}{l}\text { Average score of three protection mechanisms: } \\
\text { patenting in the EU; patenting in the US; and } \\
\text { trademarks (rescaled from } 0 \text { to } 1 \text { ) - Cronbach's } \\
\alpha=0.63\end{array}$ & $\begin{array}{c}0.189 \\
(0.291)\end{array}$ & $\begin{array}{c}0.145 \\
(0.270)\end{array}$ & $\begin{array}{c}0.228 \\
(0.307)\end{array}$ & $\begin{array}{c}0.236 \\
(0.301)\end{array}$ & $\begin{array}{c}0.126 \\
(0.218)\end{array}$ & $\begin{array}{c}0.292 \\
(0.358)\end{array}$ & $\begin{array}{c}0.164 \\
(0.272)\end{array}$ & $\begin{array}{c}0.107 \\
(0.184)\end{array}$ \\
\hline $\begin{array}{l}\text { Degree of internationalization } \\
\text { (Export) }\end{array}$ & $\begin{array}{l}\mathrm{DV}=1 \text { if firms engage in exporting activities; } \\
\text { zero otherwise }\end{array}$ & $\begin{array}{c}0.677 \\
(0.468)\end{array}$ & $\begin{array}{c}0.592 \\
(0.492)\end{array}$ & $\begin{array}{c}0.740 \\
(0.440)\end{array}$ & $\begin{array}{c}0.793 \\
(0.407)\end{array}$ & $\begin{array}{c}0.606 \\
(0.491)\end{array}$ & $\begin{array}{c}0.814 \\
(0.390)\end{array}$ & $\begin{array}{c}0.648 \\
(0.479)\end{array}$ & $\begin{array}{c}0.551 \\
(0.500)\end{array}$ \\
\hline The age of firm $(A g e)$ & $\begin{array}{l}\text { Natural logarithm of firm age in the reference } \\
\text { year }\end{array}$ & $\begin{array}{l}2.606 \\
(0.714)\end{array}$ & $\begin{array}{c}2.276 \\
(0.645)\end{array}$ & $\begin{array}{c}2.777 \\
(0.573)\end{array}$ & $\begin{array}{c}3.178 \\
(0.638)\end{array}$ & $\begin{array}{c}2.405 \\
(0.546)\end{array}$ & $\begin{array}{c}2.580 \\
(0.718)\end{array}$ & $\begin{array}{c}2.851 \\
(0.746)\end{array}$ & $\begin{array}{l}2.528 \\
(0.734)\end{array}$ \\
\hline Competitive pressure & Categorical variable $=1$ if the response was & 3.798 & 3.658 & 3.905 & 3.983 & 3.874 & 3.757 & 3.824 & 3.754 \\
\hline (Competition) & $\begin{array}{l}\text { 'Very weak'; =2 if the response was 'Weak'; =3 } \\
\text { if the response was 'Moderate; }=4 \text { if the } \\
\text { response was 'Strong'; }=5 \text { if the firm responded } \\
\text { 'Very strong' to the question "How would you } \\
\text { judge the competition in your main market(s)" }\end{array}$ & $(1.036)$ & $(1.097)$ & $(0.970)$ & $(0.932)$ & $(1.054)$ & $(0.989)$ & $(1.059)$ & $(1.070)$ \\
\hline $\begin{array}{l}\text { Existence of a separate } \mathrm{R} \& \mathrm{D} \\
\text { department }(R \& D \text { department })\end{array}$ & $\begin{array}{l}\mathrm{DV}=1 \text { if firms have a separate } \mathrm{R} \& \mathrm{D} \\
\text { department; zero otherwise }\end{array}$ & $\begin{array}{c}0.415 \\
(0.493)\end{array}$ & $\begin{array}{c}0.303 \\
(0.460)\end{array}$ & $\begin{array}{c}0.445 \\
(0 . .498)\end{array}$ & $\begin{array}{c}0.655 \\
(0.477)\end{array}$ & $\begin{array}{c}0.441 \\
(0.498)\end{array}$ & $\begin{array}{c}0.552 \\
(0.498)\end{array}$ & $\begin{array}{c}0.321 \\
(0.468)\end{array}$ & $\begin{array}{c}0.271 \\
(0.446)\end{array}$ \\
\hline $\begin{array}{l}\text { Location in a technology park } \\
\text { (Technology park) }\end{array}$ & $\begin{array}{l}\mathrm{DV}=1 \text { if firms are located in a technology } \\
\text { park/area; zero otherwise }\end{array}$ & $\begin{array}{c}0.261 \\
(0.440)\end{array}$ & $\begin{array}{c}0.326 \\
(0.469)\end{array}$ & $\begin{array}{c}0.220 \\
(0.415)\end{array}$ & $\begin{array}{c}0.164 \\
(0.372)\end{array}$ & $\begin{array}{c}0.299 \\
(0.460)\end{array}$ & $\begin{array}{c}0.371 \\
(0.484)\end{array}$ & $\begin{array}{c}0.158 \\
(0.365)\end{array}$ & $\begin{array}{c}0.169 \\
(0.377)\end{array}$ \\
\hline $\begin{array}{l}\text { Integration in a technology } \\
\text { platform (Technology platform) }\end{array}$ & $\begin{array}{l}\text { DV=1 if firms integrate a cluster/technology } \\
\text { platform; zero otherwise }\end{array}$ & $\begin{array}{c}0.252 \\
(0.434)\end{array}$ & $\begin{array}{c}0.220 \\
(0.415)\end{array}$ & $\begin{array}{c}0.280 \\
(0.450)\end{array}$ & $\begin{array}{c}0.284 \\
(0.453)\end{array}$ & $\begin{array}{c}0.283 \\
(0.452)\end{array}$ & $\begin{array}{c}0.262 \\
(0.441)\end{array}$ & $\begin{array}{c}0.236 \\
(0.426)\end{array}$ & $\begin{array}{c}0.220 \\
(0.416)\end{array}$ \\
\hline $\begin{array}{l}\text { Percentage of full-time } \\
\text { employees dedicated to } R \& D \\
\text { activities ( } R \& D \text { personnel) }\end{array}$ & $\begin{array}{l}\text { Categorical variable }=1 \text { if the share is } 0-10 \% \text {; } \\
=2 \text { if the share is } 11-20 \% ;=3 \text { if the share is } 21- \\
50 \% ;=4 \text { if the share is }>50 \%\end{array}$ & $\begin{array}{c}2.150 \\
(1.214)\end{array}$ & $\begin{array}{c}2.411 \\
(1.287)\end{array}$ & $\begin{array}{c}2.000 \\
(1.121)\end{array}$ & $\begin{array}{l}1.724 \\
(1.001)\end{array}$ & $\begin{array}{c}2.354 \\
(1.165)\end{array}$ & $\begin{array}{c}2.581 \\
(1.255)\end{array}$ & $\begin{array}{c}1.684 \\
(1.047)\end{array}$ & $\begin{array}{c}1.814 \\
(1.093)\end{array}$ \\
\hline $\begin{array}{l}\text { Resources devoted to innovation } \\
\text { (Resources) }\end{array}$ & $\begin{array}{l}\text { DV=1 if the firm's response to the question } \\
\text { "Five years ago did you devote?" was 'Fewer } \\
\text { resources to innovation'; = } 0 \text { if 'About the same' } \\
\text { or 'More'. }\end{array}$ & $\begin{array}{c}0.453 \\
(0.498)\end{array}$ & $\begin{array}{c}0.444 \\
(0.498)\end{array}$ & $\begin{array}{c}0.460 \\
(0.470)\end{array}$ & $\begin{array}{c}0.466 \\
(0.501)\end{array}$ & $\begin{array}{c}0.528 \\
(0.501)\end{array}$ & $\begin{array}{c}0.419 \\
(0.495)\end{array}$ & $\begin{array}{c}0.400 \\
(0.491)\end{array}$ & $\begin{array}{c}0.508 \\
(0.502)\end{array}$ \\
\hline $\begin{array}{l}\text { Past innovation capacity relative } \\
\text { to competitors (Innovation } \\
\text { capacity) }\end{array}$ & $\begin{array}{l}\text { DV = } 1 \text { if the firm's innovation capacities within } \\
\text { the industry in } 2005 \text { was 'Above average' and } \\
\text { 'Leading'; = } 0 \text { for 'Average' and 'Lagging' }\end{array}$ & $\begin{array}{c}0.237 \\
(0.426)\end{array}$ & $\begin{array}{c}0.253 \\
(0.436)\end{array}$ & $\begin{array}{c}0.265 \\
(0.442)\end{array}$ & $\begin{array}{c}0.147 \\
(0.355)\end{array}$ & $\begin{array}{c}0.236 \\
(0.426)\end{array}$ & $\begin{array}{c}0.276 \\
(0.448)\end{array}$ & $\begin{array}{c}0.182 \\
(0.387)\end{array}$ & $\begin{array}{c}0.246 \\
(0.432)\end{array}$ \\
\hline Micro firms & $\begin{array}{l}\mathrm{DV}=1 \text { if the firm has fewer than } 10 \text { employees; } \\
\text { zero otherwise }\end{array}$ & $\begin{array}{c}0.490 \\
(0.500)\end{array}$ & - & - & - & $\begin{array}{c}0.575 \\
(0.496)\end{array}$ & $\begin{array}{c}0.457 \\
(0.499)\end{array}$ & $\begin{array}{c}0.394 \\
(0.490)\end{array}$ & $\begin{array}{c}0.593 \\
(0.493)\end{array}$ \\
\hline Small firms & $\begin{array}{l}\mathrm{DV}=1 \text { if the firm has more than } 10 \text { and fewer } \\
\text { than } 50 \text { employees; zero otherwise }\end{array}$ & $\begin{array}{c}0.323 \\
(0.468)\end{array}$ & - & - & - & $\begin{array}{c}0.268 \\
(0.445)\end{array}$ & $\begin{array}{c}0.391 \\
(0.489)\end{array}$ & $\begin{array}{c}0.339 \\
(0.475)\end{array}$ & $\begin{array}{c}0237 \\
(0.427)\end{array}$ \\
\hline Medium firms & $\begin{array}{l}\mathrm{DV}=1 \text { if the firm has more than } 50 \text { and fewer } \\
\text { than } 250 \text { employees; zero otherwise }\end{array}$ & $\begin{array}{c}0.187 \\
(0.390)\end{array}$ & - & - & - & $\begin{array}{c}0.157 \\
(0.366)\end{array}$ & $\begin{array}{c}0.152 \\
(0.360)\end{array}$ & $\begin{array}{c}0.267 \\
(0.444)\end{array}$ & $\begin{array}{c}0.170 \\
(0.377)\end{array}$ \\
\hline $\begin{array}{l}\text { 'Innovation leaders', that is, } \\
\text { countries whose performance is }\end{array}$ & $\begin{array}{l}\text { DV=1 if countries are Denmark, Finland, } \\
\text { Germany and Sweden; zero otherwise }\end{array}$ & $\begin{array}{c}0.184 \\
(0.388)\end{array}$ & $\begin{array}{c}0.181 \\
(0.386)\end{array}$ & $\begin{array}{c}0.215 \\
(0.412) \\
\end{array}$ & $\begin{array}{c}0.138 \\
(0.346) \\
\end{array}$ & $\begin{array}{c}0.118 \\
(0.324)\end{array}$ & $\begin{array}{c}0.252 \\
(0.435) \\
\end{array}$ & $\begin{array}{c}0.164 \\
(0.272)\end{array}$ & $\begin{array}{c}0.161 \\
(0.369) \\
\end{array}$ \\
\hline
\end{tabular}




\begin{tabular}{|c|c|c|c|c|c|c|c|c|c|}
\hline \multicolumn{10}{|l|}{$\begin{array}{l}\text { well above the EU27 average } \\
\text { (Leaders) }\end{array}$} \\
\hline $\begin{array}{l}\text { 'Innovation followers', that is, } \\
\text { countries whose performance is } \\
\text { close to that of the EU } 27 \text { average } \\
\text { (Followers) }\end{array}$ & $\begin{array}{l}\text { DV }=1 \text { if countries are Austria, Belgium, } \\
\text { Cyprus, Estonia, France, Ireland, Luxembourg, } \\
\text { Netherlands, Slovenia and the United Kingdom; } \\
\text { zero otherwise (base category) }\end{array}$ & $\begin{array}{c}0.319 \\
(0.467)\end{array}$ & $\begin{array}{c}0.355 \\
(0.479)\end{array}$ & $\begin{array}{c}0.300 \\
(0.459)\end{array}$ & $\begin{array}{c}0.259 \\
(0.440)\end{array}$ & $\begin{array}{c}0.323 \\
(0.469)\end{array}$ & $\begin{array}{c}0.286 \\
(0.453)\end{array}$ & $\begin{array}{c}0.309 \\
(0.464)\end{array}$ & $\begin{array}{c}0.390 \\
(0.490)\end{array}$ \\
\hline $\begin{array}{l}\text { 'Moderate innovators', that is, } \\
\text { countries whose performance is } \\
\text { below that of the EU } 27 \text { average } \\
\text { (Moderate) }\end{array}$ & $\begin{array}{l}\text { DV=1 if countries are Czech Republic, Greece, } \\
\text { Hungary, Italy, Malta, Poland, Portugal, } \\
\text { Slovakia and Spain; zero otherwise }\end{array}$ & $\begin{array}{c}0.390 \\
(0.488)\end{array}$ & $\begin{array}{c}0.359 \\
(0.480)\end{array}$ & $\begin{array}{c}0.390 \\
(0.490)\end{array}$ & $\begin{array}{c}0.474 \\
(0.501)\end{array}$ & $\begin{array}{c}0.425 \\
(0.496)\end{array}$ & $\begin{array}{c}0.424 \\
(0.495)\end{array}$ & $\begin{array}{c}0.406 \\
(0.493)\end{array}$ & $\begin{array}{c}0.271 \\
(0.446)\end{array}$ \\
\hline $\begin{array}{l}\text { 'Modest innovators', that is, } \\
\text { countries whose performance is } \\
\text { well below that of the EU } 27 \\
\text { average (Modest) }\end{array}$ & $\begin{array}{l}\mathrm{DV}=1 \text { if countries are Bulgaria, Latvia, } \\
\text { Lithuania, Romania and Bosnia and } \\
\text { Herzegovina; zero otherwise }\end{array}$ & $\begin{array}{c}0.106 \\
(0.309)\end{array}$ & $\begin{array}{c}0.105 \\
(0.307)\end{array}$ & $\begin{array}{c}0.095 \\
(0.294)\end{array}$ & $\begin{array}{c}0.129 \\
(0.337)\end{array}$ & $\begin{array}{c}0.134 \\
(0.342)\end{array}$ & $\begin{array}{c}0.038 \\
(0.192)\end{array}$ & $\begin{array}{c}0.121 \\
(0.327)\end{array}$ & $\begin{array}{c}0.178 \\
(0.384)\end{array}$ \\
\hline High-technology industries & $\begin{array}{l}\mathrm{DV}=1 \text { if firms operate in high-technology } \\
\text { intensive industries; zero otherwise (NACE } \\
\text { classification rev 1.1) }\end{array}$ & $\begin{array}{c}0.202 \\
(0.402)\end{array}$ & $\begin{array}{c}0.201 \\
(0.401)\end{array}$ & $\begin{array}{c}0.265 \\
(0.442)\end{array}$ & $\begin{array}{c}0.095 \\
(0.294)\end{array}$ & - & - & - & - \\
\hline $\begin{array}{l}\text { Medium high-technology } \\
\text { industries }\end{array}$ & $\begin{array}{l}\text { DV=1 if firms operate in medium high- } \\
\text { technology intensive industries; zero otherwise }\end{array}$ & $\begin{array}{c}0.137 \\
(0.344)\end{array}$ & $\begin{array}{c}0.115 \\
(0.320)\end{array}$ & $\begin{array}{c}0.145 \\
(0.353)\end{array}$ & $\begin{array}{c}0.181 \\
(0.387)\end{array}$ & - & - & - & - \\
\hline $\begin{array}{l}\text { Medium low-technology } \\
\text { industries }\end{array}$ & $\begin{array}{l}\mathrm{DV}=1 \text { if firms operate in medium low- } \\
\text { technology intensive industries; zero otherwise }\end{array}$ & $\begin{array}{c}0.134 \\
(0.341)\end{array}$ & $\begin{array}{c}0.115 \\
(0.320)\end{array}$ & $\begin{array}{c}0.120 \\
(0.326)\end{array}$ & $\begin{array}{c}0.207 \\
(0.407)\end{array}$ & - & - & - & - \\
\hline Low-technology industries & $\begin{array}{l}\mathrm{DV}=1 \text { if firms operate in low-technology } \\
\text { intensive industries; zero otherwise }\end{array}$ & $\begin{array}{c}0.132 \\
(0.339)\end{array}$ & $\begin{array}{c}0.099 \\
(0.299)\end{array}$ & $\begin{array}{c}0.160 \\
(0.368)\end{array}$ & $\begin{array}{c}0.172 \\
(0.379)\end{array}$ & - & - & - & - \\
\hline $\begin{array}{l}\text { Information and Communication } \\
\text { Technology (ICT) industries }\end{array}$ & $\begin{array}{l}\text { DV }=1 \text { if firms operate in ICT industries; zero } \\
\text { otherwise }\end{array}$ & $\begin{array}{l}0.205 \\
(0.404)\end{array}$ & $\begin{array}{c}0.240 \\
(0.428)\end{array}$ & $\begin{array}{c}0.170 \\
(0.377)\end{array}$ & $\begin{array}{c}0.172 \\
(0.379)\end{array}$ & - & - & - & - \\
\hline Service sectors & $\begin{array}{l}\text { DV }=1 \text { if firms operate in service industries; zero } \\
\text { otherwise (base category) }\end{array}$ & $\begin{array}{c}0.190 \\
(0.393)\end{array}$ & $\begin{array}{c}0.230 \\
(0.422)\end{array}$ & $\begin{array}{c}0.140 \\
(0.348)\end{array}$ & $\begin{array}{c}0.173 \\
(0.379) \\
\end{array}$ & - & - & - & - \\
\hline
\end{tabular}

Notes: SD denotes standard deviation. 
Table A2. Correlation coefficients

\begin{tabular}{|c|c|c|c|c|c|c|c|c|c|c|}
\hline 1. Export & $\begin{array}{r}1 . \\
1.000\end{array}$ & 2. & 3. & 4. & 5 . & 6. & 7. & 8. & 9. & 10 . \\
\hline 2. Age & $0.062 *$ & 1.000 & & & & & & & & \\
\hline 3. Competition & 0.012 & $0.112 * * *$ & 1.000 & & & & & & & \\
\hline 4. R\&D personnel & $0.183 * * *$ & $-0.273 * * *$ & $-0.147 * * *$ & 1.000 & & & & & & \\
\hline 5. R\&D department & $0.232 * * *$ & $0.087 *$ & 0.012 & $0.321 * * *$ & 1.000 & & & & & \\
\hline 6. Resources & 0.012 & -0.031 & $0.089 * *$ & $0.074 * *$ & $0.108 * * *$ & 1.000 & & & & \\
\hline 7. Innovation capacity & $0.137 * * *$ & $-0.067 *$ & $-0.105 * * *$ & $0.317 * * *$ & $0.112 * * *$ & $-0.101 * * *$ & 1.000 & & & \\
\hline 8. Technology park & $0.088 * *$ & $-0.272 * * *$ & $-0.118 * * *$ & $0.298 * * *$ & $0.085^{* *}$ & 0.049 & $0.109 * * *$ & 1.000 & & \\
\hline 9. Technology platform & $0.098 * * *$ & -0.051 & 0.037 & $0.169 * * *$ & $0.139 * * *$ & $0.218 * * *$ & 0.040 & $0.236 * * *$ & 1.000 & \\
\hline 10. IP protection & $0.197 * * *$ & 0.044 & $-0.067 *$ & $0.255^{* * *}$ & $0.286 * * *$ & $0.076 * *$ & $0.187 * * *$ & $0.170 * * *$ & $0.139 * * *$ & 1.000 \\
\hline 11. Source_brokers & 0.015 & 0.002 & -0.004 & 0.004 & $0.062 *$ & -0.001 & 0.008 & -0.036 & 0.021 & -0.029 \\
\hline 12. Source_other_firms & $0.135 * * *$ & -0.057 & -0.044 & $0.165^{* * *}$ & $0.098 * *$ & 0.055 & $0.084 * *$ & 0.011 & 0.029 & 0.015 \\
\hline 13. Source_research & $0.186 * * *$ & -0.051 & $-0.100 * * *$ & $0.295 * * *$ & $0.188 * * *$ & $0.070 *$ & $0.176 * * *$ & 0.114 & $0.155 * * *$ & $0.143 * * *$ \\
\hline 14. Source_strategic & $0.118 * * *$ & $-0.175^{* * *} *$ & $-0.067 *$ & $0.228 * * *$ & $0.097 * *$ & $0.111 * * *$ & $0.147 * * *$ & 0.099 & $0.141 * * *$ & $0.082 * *$ \\
\hline 15. Source_non_equity & $0.057 * * *$ & $-0.121 * * *$ & 0.004 & $0.163 * * *$ & $0.079 * *$ & $0.160 * * *$ & $0.082 * *$ & 0.075 & $0.117 * * *$ & $0.089 * *$ \\
\hline 16. Source_networks & $0.093 * *$ & $-0.122 * * *$ & $-0.073 *$ & $0.244 * * *$ & $0.129 * * *$ & $0.135 * * *$ & $0.098 * *$ & 0.159 & $0.298 * * *$ & 0.042 \\
\hline 17. Source_customers & $0.156 * * *$ & $-0.070^{*}$ & -0.032 & $0.164 * * *$ & $0.095 * *$ & $0.075^{*}$ & $0.205 * * *$ & 0.085 & $0.128 * * *$ & 0.054 \\
\hline
\end{tabular}

Notes: $* * * p<0.01, * * p<0.05, * p<0.1$. 
Table A3. Correlation coefficients (continued)

\begin{tabular}{|c|c|c|c|c|c|c|c|}
\hline 11. Source brokers & $\begin{array}{r}11 . \\
1000\end{array}$ & 12. & 13. & 14. & 15. & 16. & 17. \\
\hline 12. Source_otherfirms & $0.185^{* * *}$ & 1.000 & & & & & \\
\hline 13. Source_research & $0.113 * * *$ & $0.525 * * *$ & 1.000 & & & & \\
\hline 14. Source_strategic & $0.101 * * *$ & $0.410 * * *$ & $0.343 * * *$ & 1.000 & & & \\
\hline 15. Source_non_equity & $0.088 * *$ & $0.363 * * *$ & $0.293 * * *$ & $0.535 * * *$ & 1.000 & & \\
\hline 16. Source_networks & 0.045 & $0.300 * * *$ & $0.383 * * *$ & $0.305 * * *$ & $0.295 * * *$ & 1.000 & \\
\hline 17. Source_customers & $0.103 * * *$ & $0.220 * * *$ & $0.236 * * *$ & $0.272 * * *$ & $0.213 * * *$ & $0.313 * * *$ & 1.000 \\
\hline
\end{tabular}

